\title{
Development of New Cancer Treatment by Identifying and Focusing the Genetic Mutations or Altered Expression in Gynecologic Cancers
}

\author{
Yun-Hsin Tang ${ }^{1,2}$, Chiao-Yun Lin ${ }^{1,2}$ and Chyong-Huey Lai ${ }^{1,2, *(\mathbb{D}}$ \\ 1 Department of Obstetrics and Gynecology, Chang Gung Memorial Hospital Linkou Branch and Chang Gung \\ University College of Medicine, Taoyuan 333, Taiwan; 8902037@cgmh.org.tw (Y.-H.T.); \\ chiao.yun0101@gmail.com (C.-Y.L.) \\ 2 Gynecologic Cancer Research Center, Chang Gung Memorial Hospital Linkou Branch and Chang Gung \\ University, Taoyuan 333, Taiwan \\ * Correspondence: laich46@cgmh.org.tw; Tel.: +886-(3)-328-1200; Fax: +886-(3)-328-8252
}

Citation: Tang, Y.-H.; Lin, C.-Y.; Lai, C.-H. Development of New Cancer Treatment by Identifying and Focusing the Genetic Mutations or Altered Expression in Gynecologic Cancers. Genes 2021, 12, 1593.

https://doi.org/10.3390/ genes12101593

Academic Editor: Hiroyuki Tsuchiya

Received: 7 September 2021

Accepted: 7 October 2021

Published: 9 October 2021

Publisher's Note: MDPI stays neutral with regard to jurisdictional claims in published maps and institutional affiliations.

Copyright: (C) 2021 by the authors. Licensee MDPI, Basel, Switzerland. This article is an open access article distributed under the terms and conditions of the Creative Commons Attribution (CC BY) license (https:// creativecommons.org/licenses/by/ $4.0 /)$.

\begin{abstract}
With the advent of next-generation sequencing (NGS), The Cancer Genome Atlas (TCGA) research network has given gynecologic cancers molecular classifications, which impacts clinical practice more and more. New cancer treatments that identify and target pathogenic abnormalities of genes have been in rapid development. The most prominent progress in gynecologic cancers is the clinical efficacy of poly(ADP-ribose) polymerase (PARP) inhibitors, which have shown breakthrough benefits in reducing hazard ratios (HRs) (HRs between 0.2 and 0.4 ) of progression or death from $B R C A 1 / 2$ mutated ovarian cancer. Immune checkpoint inhibition is also promising in cancers that harbor mismatch repair deficiency (dMMR)/microsatellite instability (MSI). In this review, we focus on the druggable genetic alterations in gynecologic cancers by summarizing literature findings and completed and ongoing clinical trials.
\end{abstract}

Keywords: homologous recombination repair; mismatch repair; ovarian cancer; endometrial cancer; gynecologic cancer

\section{Introduction}

According to the Global Cancer Statistics 2020, cervical cancer, corpus cancer, and ovarian cancer were the fourth, sixth, and seventh in incidence and fourth, eleventh, and seventh in mortality rates among female malignancies [1]. Epithelial ovarian cancer (EOC) accounts for $90 \%$ of ovarian malignancies. Approximately $75 \%$ of EOC patients are diagnosed at an advanced stage with a 5-year survival rate of around 20-30\% [2]. Uterine corpus cancer, mainly diagnosed in early stages, is associated with favorable survival, except for advanced stage or aggressive histologic types [3]. Cancer of the uterine cervix is mainly caused by viral etiology (human papillomavirus (HPV) infections), while different integration signatures related to HPV genotypes were found [4]. Aggressive chemotherapy, radiotherapy, and targeted therapy with anti-angiogenesis agents have improved survival of gynecologic cancers [5-7]. However, patients with recurrent/refractory diseases have rapid progression, and most of them will die of disease. There are still unmet needs in current treatment in gynecologic cancers.

With the advent of next-generation sequencing (NGS), The Cancer Genome Atlas (TCGA) research network has given gynecologic cancers molecular classifications, which impacts clinical practice more and more [8-10]. EOC has more frequent mutations in TP53, FOXM1, RB, PI3K/RAS, NOTCH pathway, and homologous recombination (HR) alterations. Endometrial cancer has more frequent mutations in the PI3K/AKT and RTK/RAS/ $\beta$-catenin pathway. Cervical cancers exhibited genomic alterations in either one or both of the PI3KMAPK and TGF $\beta$ pathways, illustrating the potential clinical significance of therapeutic agents targeting members of these pathways [8-10] (Figure 1). 
(A)

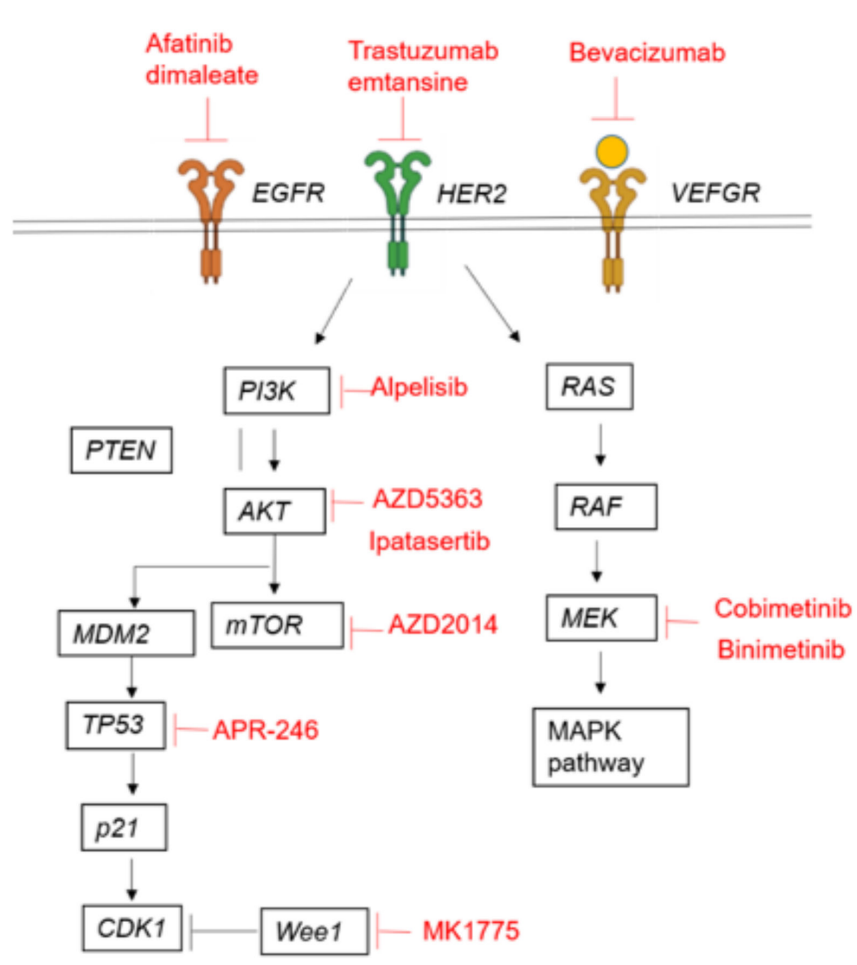

(B)

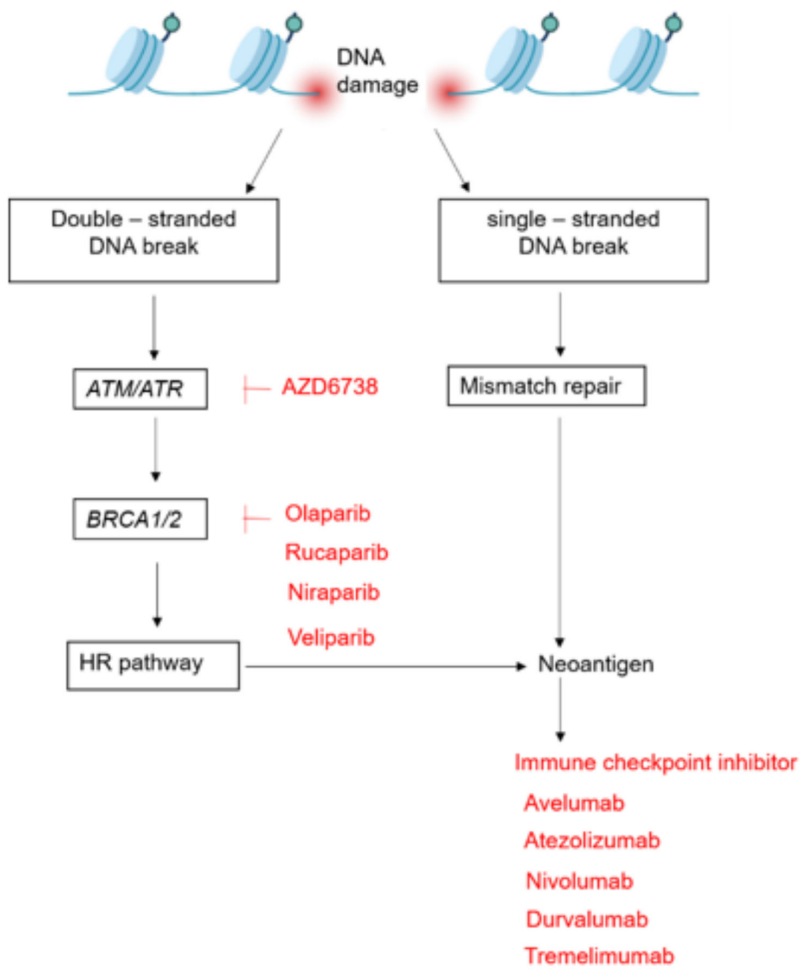

Figure 1. Altered pathways in gynecologic cancers. (A) The regulatory functions of oncogenic and tumor suppressor genes in the RTK (receptor tyrosine kinase) signaling pathway. (B) DNA damage repair pathways. The inhibitors against gene describe the rationale of therapies in cancer treatment (signed by red words).

New cancer treatments that identify and target pathogenic abnormalities of genes have been in rapid development. In this review, we focus on the druggable genetic alterations in gynecologic cancers by summarizing literature findings and the clinical efficacy of clinical trials. We further describe the ongoing trials and potential drugs that are under development.

\section{Alterations in Homologous Recombination Pathway as a Biomarker and Target of Cancer Therapies}

\subsection{BRCA1/2 Mutations}

The homologous recombination (HR) pathway plays a pivotal role in the repair of DNA double-strand breaks (DSBs) and inter-strand crosslinks, which maintain genomic stability by cooperation with the Faconi Anemia (FA) pathway [8]. Approximately 50\% of epithelial ovarian cancers (EOC) harbor genetic and epigenetic alterations of the HR pathway genes [8]. Women with diagnosed EOC should have germline or somatic genetic testing for $B R C A 1 / 2$ variants [11]. Germline $B R C A 1$ and $B R C A 2$ mutations are the most common genetic alterations, which are observed in 15 to $20 \%$ of all EOCs [2]. Ovarian cancer patients with germline $B R C A$ mutations had a better survival rate with a generally favorable response to platinum-based chemotherapy, compared to patients who were $B R C A$-wild type $[8,12-15]$. Somatic mutation of $B R C A 1$ and $B R C A 2$ have been identified in $6 \%$ of EOCs [8]. A total of $81 \%$ of $B R C A 1$ and $72 \%$ of $B R C A 2$ mutations are heterozygous loss, and the majority of germline and somatic mutations are frameshift insertions or deletions [8].

\subsection{Homologous Recombination Repair Genes beyond BRCA1/2}

In addition to $B R C A 1 / 2$, the homologous recombination repair (HRR) genes that have been identified and applied in studies are ATM, ATR, BARD1, BLM, BRIP1, CDK12, 
CHEK1, CHEK2, FANCA, FANCC, FANCD2, FANCE, FANCF, FANCI, FANCL, FANCM, MRE11, NBN, PALB2, RAD50, RAD51, RAD51B, RAD51C, RAD51D, RAD52, RAD54L, and RPA1 [16-18]. The homologous recombination deficiency (HRD) score integrates three independent DNA-based measurements of genomic instability, including loss of heterozygosity (LOH), telomeric allelic imbalance (TAI), and large-scale transitions (LST) in the tumor tissue [19]. HRD has been shown to be a predictive biomarker of PARPi therapy beyond BRCA status [19].

\subsection{Poly(ADP-ribose) Polymerase (PARP) Inhibition in Epithelial Ovarian Cancer \\ 2.3.1. PARP and PARP Inhibitor}

PARP inhibitors (PARPi), the first synthetic lethal drugs that are the first clinically approved, are targeting in HRD cancers, which have the defect in the homologous recombination repair pathway, the conservative mechanism of repair of DSBs [20]. PARP enzymes involve a number of cellular pathways that regulate energy metabolism, gene transcription, cell death, and epigenetic modifications [21-23]. There are 17 members in the PARP family, and PARP1, PARP2, and PARP3 are related to DNA repair [24]. PARP shares a synthetic lethal relationship with $B R A C 1 / 2$, both of which are key in DNA double-strand break repair [24,25]. With PARP inhibition, persistent single-strand DNA breaks (SSBs), which are repaired through active base-excision repair pathways, lead to the accumulation of doublestrand breaks. In HRD cancer cells, those DSBs are not repaired, which leads to cell death. Other mechanisms of PARP inhibitors include PARP1 trapping, activation of error-prone nonhomologous end joining (NHEJ), and impaired BRCA1 recruitment [20,24,26-31].

PARPis, including olaparib (AZD2281, KuDOS/AstraZeneca), niraparib (MK4827, Merck/Tesaro), rucaparib (CO338, AG014699, and PF01367338, Pfizer/Clovis), and veliparib (ABT888, Abbvie), all interact with the binding site of the PARP enzyme cofactor, $\beta-N A D+$, in the catalytic domain of PARP1 and PARP2. PARPi have been extensively studied in epithelial ovarian cancers (Table 1) [32-42]. A second-generation PARPi, talazoparib (Lead/Biomarin/Medivation/Pfizer), has been developed. Talazoparib is more potent in trapping PARP1 protein on DNA, preventing autoPARylation and PARP1 release from the site of damage, interfering with the catalytic cycle of PARP1, and has a higher in-vitro cytotoxicity in BRCA mutant cells compared with olaparib [20,43]. Talazoparib has been approved for adults with deleterious or suspected deleterious germline BRCA-mutated, human epidermal growth factor receptor 2 (HER2)-negative, locally advanced, or metastatic breast cancer, but with limited evidence in EOCs [20,44,45]. 
Table 1. Results of phase II/III clinical trials of PARP inhibitors in ovarian cancer.

\begin{tabular}{|c|c|c|c|c|c|c|c|}
\hline Study/NCT Identifier & Design & Patient No. & Treatment & Patient Population & Efficacy & $\mathrm{AE} \geq$ Grade 3 & Genetic Testing \\
\hline \multicolumn{8}{|c|}{ Olaparib (Lynparza, AstraZeneca) } \\
\hline $\begin{array}{l}\text { Study } 19 \text { [32], } \\
\text { NCT00753545 }\end{array}$ & $\begin{array}{l}\text { Phase II, } \\
\text { double-blind, } \\
\text { randomized }\end{array}$ & 265 & $\begin{array}{l}\text { Olaparib } 400 \mathrm{mg} \text { vs. placebo } \\
\text { orally, BID (1:1) }\end{array}$ & $\begin{array}{l}\text { Recurrent } \\
\text { platinum-sensitive, } \\
\text { HGSOC, } \\
\geq 2 \text { platinum-based } \\
\text { chemotherapy }\end{array}$ & $\begin{array}{l}\text { PFS: } 8.4 \text { mo vs. } 4.8 \text { mo; HR, } 0.35 ; \\
p<0.001 \\
\text { - } \quad \text { BRCA } A^{\text {mut }}: 11.2 \text { vs. } 4.3 \mathrm{mo}, \\
\text { HR } 0.18, p<0.0001 \\
\text { - } \quad \text { BRCA } A^{\text {wot }}: 7.4 \text { vs. } 5.5 \mathrm{mo}, \\
\quad \text { HR } 0.54, p=0.0075 \\
\text { - } \quad \text { ORR: } 12 \% \text { vs. } 4 \%(p=0.12)\end{array}$ & $\begin{array}{ll}- & \text { Fatigue }(6.6 \%) \\
- & \text { Anemia }(5.1 \%) \\
\text { - } & \text { Nausea/vomiting }(4.4 \%) \\
& \text { Diarrhea }(2.2 \%)\end{array}$ & \\
\hline $\begin{array}{l}\text { SOLO } 1 \text { [35], } \\
\text { NCT01844986 }\end{array}$ & $\begin{array}{l}\text { Phase III, } \\
\text { double-blind, } \\
\text { RCT }\end{array}$ & 391 & $\begin{array}{l}\text { Olaparib } 300 \mathrm{mg} \text { vs. placebo } \\
\text { orally, BID (2:1) } \\
\text { Maintenance up to } 24 \mathrm{mo}\end{array}$ & $\begin{array}{l}\text { Newly diagnosed, } \\
\text { advanced, HGSOC or } \\
\text { endometrioid OC, } \\
\text { gBRCA1/2 } 2^{\text {mut }}, C R \text { or } \\
\text { PR after platinum-based } \\
\text { chemotherapy }\end{array}$ & 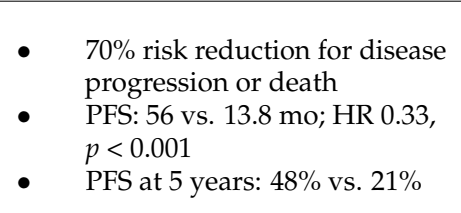 & $\begin{array}{ll}- & \text { Fatigue }(4 \%) \\
- & \text { Anemia }(22 \%) \\
- & \text { Nausea/vomiting }(1.1 \%) \\
\text { - } & \text { Neutropenia }(9 \%) \\
& \text { Thrombocytopenia }(1 \%)\end{array}$ & $\begin{array}{ll}\text { - } & \text { Myriad's } \\
\text { BRACAnalysis } \\
\text { CDx (germline) } \\
\text { - } \quad \text { Foundation One } \\
\text { CDx (tissue) }\end{array}$ \\
\hline $\begin{array}{l}\text { PAOLA-1/ENGOT- } \\
\text { ov25 [36], } \\
\text { NCT02477644 }\end{array}$ & $\begin{array}{l}\text { Phase III, } \\
\text { double-blind, } \\
\text { RCT }\end{array}$ & 806 & $\begin{array}{l}\text { Olaparib } 300 \mathrm{mg} \text { orally BID } \\
(24 \mathrm{mo})+\text { bevacizumab } \\
(15 \mathrm{mo}) 15 \mathrm{mg} / \mathrm{kg} \text { every } \\
3 \text { weeks vs. placebo }+ \\
\text { bevacizumab }(15 \mathrm{mo})(2: 1) \\
\text { Maintenance }\end{array}$ & $\begin{array}{l}\text { Newly diagnosed, } \\
\text { advanced high-grade } \\
\text { EOC, CR or PR after } \\
\text { platinum-taxane based } \\
\text { chemotherapy }\end{array}$ & $\begin{array}{ll}\text { - } & 67 \% \text { risk reduction for disease } \\
& \text { progression or death } \\
\text { - } & \text { PFS: } \\
\text { - } & \text { All: } 22.1 \text { vs. } 16.6 \mathrm{mo} \text { HR } 0.56, \\
& p<0.001 \\
\text { - } & \text { BRCAmut: } 37.2 \text { vs. } 21.7 \text { mo, } \\
\text { - } & \text { HR } 0.31 \\
& \text { HRD: } 37.2 \text { vs. } 17.1 \mathrm{mo}, \\
& \text { HR } 0.33 \\
\text { - } & \text { HRD/BRCAwt: } 28.1 \mathrm{vs.} \\
& 16.6 \mathrm{mo}, \mathrm{HR} 0.43 \\
\text { - } & \text { BRCAmut: HR } 0.31 \\
\text { - } & \text { HRP: } 16.9 \text { vs. } 16.0 \mathrm{mo}, \\
& \text { HR } 0.92\end{array}$ & $\begin{array}{ll}- & \text { Fatigue }(5 \%) \\
- & \text { Anemia }(17 \%) \\
- & \text { Nausea/vomiting }(3 \%) \\
- & \text { Neutropenia }(6 \%) \\
- & \text { Thrombocytopenia }(2 \%) \\
- & \text { Hypertension }(19 \%)\end{array}$ & $\begin{array}{l}\text { - } \quad \text { Myriad's } \\
\text { myChoice }{ }^{\circledR} \text { HRD } \\
\text { CDx assay }(\mathrm{HRD}: \\
\text { tumor score } \geq 42)\end{array}$ \\
\hline
\end{tabular}


Table 1. Cont

\begin{tabular}{|c|c|c|c|c|c|c|c|}
\hline Study/NCT Identifier & Design & Patient No. & Treatment & Patient Population & Efficacy & $\mathrm{AE} \geq$ Grade 3 & Genetic Testing \\
\hline \multicolumn{8}{|c|}{ Rucaparib (Rubraca, Clovis) } \\
\hline $\begin{array}{l}\text { ARIEL2 [37] } \\
\text { (NCT01891344) }\end{array}$ & $\begin{array}{l}\text { Phase III, } \\
\text { part } 1\end{array}$ & 204 & $\begin{array}{l}\text { Rucaparib } 600 \mathrm{mg} \text { orally, } \\
\text { BID, } 28 \text { day cycles }\end{array}$ & $\begin{array}{l}\text { Recurrent } \\
\text { platinum-sensitive } \\
\text { HGOC }\end{array}$ & $\begin{array}{l}\text { PFS: } \\
\text { - } \quad \text { BRCAmut: } 12.8 \mathrm{mo}, \mathrm{HR} 0.27, \\
\quad p<0.0001 \\
\text { - } \quad \text { OOHhi: } 5.7 \mathrm{mo}, \mathrm{HR} 0.62, \\
\quad \quad \quad \text { =0.011 } \\
\quad \text { LOHlo: } 5.2 \mathrm{mo}\end{array}$ & $\begin{array}{ll}- & \text { Fatigue }(9 \%) \\
- & \text { Anemia }(22 \%), \\
- & \text { Nausea / vomiting }(6 \%) \\
- & \text { Neutropenia }(7 \%) \\
- & \text { Thrombocytopenia }(2 \%)\end{array}$ & $\begin{array}{ll}\text { - } & \text { Foundation } \\
& \text { Medicine's T5 } \\
\text { - } & \text { next-generation } \\
& \text { sequencing assay } \\
\text { for tumor HRD } \\
\text { and genomic LOH } \\
\text { (LOHhi: genomic } \\
\text { LOH } \geq 14 \% \text { ) } \\
\text { Methylation- } \\
\text { sensitive PCR for } \\
\text { BRCA1 and } \\
\text { RAD51C } \\
\text { promoter } \\
\text { hypermethylation }\end{array}$ \\
\hline $\begin{array}{l}\text { ARIEL3 [38,39] } \\
\text { (NCT01968213) }\end{array}$ & Phase III, RCT & 564 & $\begin{array}{l}\text { Rucaparib } 600 \mathrm{mg} \text { orally } \\
\text { BID vs. placebo (2:1) }\end{array}$ & $\begin{array}{l}\text { Recurrent HGSOC or } \\
\text { endometrioid OC with } \\
\text { response to the last } \\
\text { platinum-based } \\
\text { chemotherapy }\end{array}$ & $\begin{array}{ll}\text { PFS: } & \\
\text { - } & \text { BRCAmut: } 16.6 \text { vs. } 5.4 \mathrm{mo}, \\
& \text { HR } 0.23, p<0.0001 \\
\text { - } & \text { HRD: } 13.6 \text { vs. } 5.4 \text { mo, } \\
& \text { HR } 0.32, p<0.0001 \\
\text { - } & \text { BRCAwt/LOHhi: } 9.7 \text { vs. } \\
& 5.4 \text { mo, HR } 0.44, p<0.0001 \\
\text { - } & \text { BRCAwt } / \text { LOHlo: } 6.7 \text { vs. } \\
& 5.4 \text { mo, HR } 0.58, p=0.0049\end{array}$ & $\begin{array}{ll}- & \text { Fatigue }(7 \%) \\
- & \text { Anemia }(22 \%) \\
- & \text { Nausea/vomiting }(8 \%) \\
- & \text { Neutropenia }(8 \%) \\
- & \text { Thrombocytopenia }(5 \%) \\
- & \text { Increased ALT or } \\
& \text { AST }(10 \%) \\
-\quad & 2 \text { treatment- } \\
& \text { related deaths }\end{array}$ & $\begin{array}{ll}\text { - } & \text { Myriad's } \\
\text { BRCAnalysis CDx } \\
\text { test (germline) } \\
\text { Foundation } \\
\text { Medicine's T5 } \\
\text { next-generation } \\
\text { sequencing } \\
\text { assay (tissue) }\end{array}$ \\
\hline \multicolumn{8}{|c|}{ Niraparib (Zejula, Tesaro) } \\
\hline $\begin{array}{l}\text { ENGOT- } \\
\text { OV16/NOVA [40] } \\
\text { (NCT01847274) }\end{array}$ & $\begin{array}{l}\text { Phase III, RCT, } \\
\text { double-blind }\end{array}$ & 533 & $\begin{array}{l}\text { Niraparib } 300 \mathrm{mg} \text { orally QD } \\
\text { vs. placebo }(2: 1) \\
\text { maintenance therapy }\end{array}$ & $\begin{array}{l}\text { Recurrent } \\
\text { platinum-sensitive, } \\
\text { EOCs (HGSOC } \\
\text { predominant), } \\
\geq 2 \text { platinum-based } \\
\text { chemotherapy }\end{array}$ & $\begin{array}{ll}\text { PFS: } \\
\text { - } \quad \text { gBRCAmut: } 21.0 \text { vs. } 5.5 \text { mo, } \\
\text { HR } 0.27, p<0.001 \\
\text { - } \quad \text { HRD/gBRCAwt: } 12.9 \text { vs. } \\
\quad 3.8 \text { mo, HR } 0.38, p<0.001 \\
\text { - } \quad \text { HRP/gBRCAwt: } 9.3 \text { vs. } \\
\quad 3.9 \text { mo, HR } 0.42, p<0.001\end{array}$ & $\begin{array}{ll}- & \text { Fatigue }(8.2 \%) \\
- & \text { Anemia }(25.3 \%) \\
- & \text { Nausea/vomiting }(4.9 \%) \\
- & \text { Neutropenia }(19.6 \%) \\
- & \text { Thrombocytopenia }(33.8 \%) \\
- & \text { Hypertension }(8.2 \%)\end{array}$ & $\begin{array}{ll}\text { - } & \text { Myriad's } \\
& \text { BRACAnalysis } \\
& \text { CDx (germline) } \\
\text { - } & \text { Myriad's } \\
& \text { myChoice }{ }^{\circledR} \text { HRD } \\
\text { - } \quad \text { CDx assay (tissue) } & \text { (HRD: tumor } \\
& \text { score } \geq 42 \text { ) }\end{array}$ \\
\hline
\end{tabular}


Table 1. Cont

\begin{tabular}{|c|c|c|c|c|c|c|c|}
\hline Study/NCT Identifier & Design & Patient No. & Treatment & Patient Population & Efficacy & $\mathrm{AE} \geq$ Grade 3 & Genetic Testing \\
\hline $\begin{array}{l}\text { PRIMA/ENGOT- } \\
\text { OV26/GOG-3012 [41] } \\
\text { (NCT02655016) }\end{array}$ & $\begin{array}{l}\text { Phase III, RCT, } \\
\text { double-blind }\end{array}$ & 733 & $\begin{array}{l}\text { Niraparib } 300 \mathrm{mg} \text { orally } \mathrm{QD} \\
\text { vs. placebo }(2: 1) \text { as } \\
\text { maintenance therapy }\end{array}$ & $\begin{array}{l}\text { Newly diagnosed, } \\
\text { advanced EOCs } \\
\text { (HGSOC predominant), } \\
\text { CR or PR after first-line } \\
\text { platinum-based } \\
\text { chemotherapy }\end{array}$ & $\begin{array}{ll}\text { PFS: } \\
\qquad \quad \text { HRD: } 21.9 \text { vs. } 10.4 \text { mo, } \\
\text { HR: } 0.43, p<0.001 \\
\text { - } \quad \text { HRP: } 8.1 \text { vs. } 5.4 \text { mo, HR } 0.68 \\
\text { All population: } 13.8 \text { vs. } \\
\quad 8.2 \text { mo, HR } 0.62, p<0.001\end{array}$ & $\begin{array}{ll}- & \text { Fatigue }(1.9 \%) \\
- & \text { Anemia }(31 \%) \\
- & \text { Nausea/vomiting }(2 \%) \\
- & \text { Neutropenia }(12.8 \%) \\
\text { - } & \text { Thrombocytopenia }(28.7 \%)\end{array}$ & $\begin{array}{ll}- & \text { myChoice }{ }^{\circledR} \mathrm{HRD} \\
& \text { CDx assay (tissue) } \\
\text { (HRD: tumor } \\
\text { score } \geq 42 \text { ) }\end{array}$ \\
\hline \multicolumn{8}{|c|}{ Veliparib (ABT-888, AbbVie) } \\
\hline $\begin{array}{l}\text { VELIA [42] } \\
\text { (NCT02470585) }\end{array}$ & Phase III, RCT & 1140 & $\begin{array}{l}\text { Carboplatin/paclitaxel plus } \\
\text { - } \quad \text { Veliparib } 150 \mathrm{mg} \\
\text { orally BID then } \\
\text { Veliparib } 400 \mathrm{mg} \text { BID } \\
\text { as maintenance } \\
\text { - } \quad \begin{array}{l}\text { Veliparib } 150 \mathrm{mg} \\
\text { orally BID then } \\
\text { placebo as }\end{array} \\
\text { maintenance } \\
\text { Placebo followed by } \\
\text { placebo as } \\
\text { maintenance (1:1:1) }\end{array}$ & $\begin{array}{l}\text { Newly diagnosed } \\
\text { advanced HGSOC }\end{array}$ & 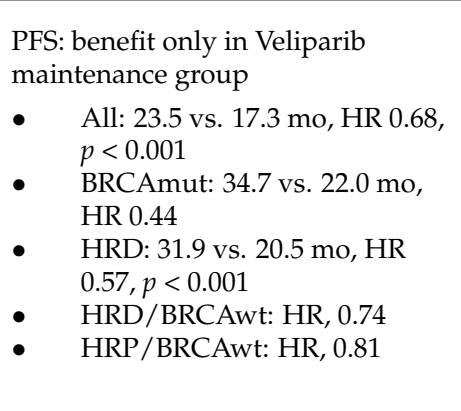 & $\begin{array}{ll}- & \text { Fatigue }(8 \%) \\
- & \text { Anemia }(38 \%) \\
- & \text { Nausea/vomiting }(12 \%) \\
\text { - } & \text { Neutropenia }(58 \%) \\
\text { - } & \text { Thrombocytopenia }(28 \%)\end{array}$ & $\begin{array}{ll}\text { - } & \text { Myriad } \\
\text { BRACAnalysis } \\
\text { CDx (germline)or } \\
\text { myChoice HRD } \\
\text { CDx assay (tissue) } \\
\text { (HRD: tumor } \\
\text { score } \geq 33 \text { ) }\end{array}$ \\
\hline
\end{tabular}




\subsubsection{Clinical Trials of PARP Inhibitors in Epithelial Ovarian Cancer Olaparib}

Study 19, a phase II randomized, double-blinded trial, evaluated maintenance therapy with olaparib in recurrent platinum-sensitive high-grade serous ovarian cancer patients who received two or more lines of platinum-based chemotherapy and had a partial or complete response in their most recent platinum-based regimen. In this trial, PFS was longer in patients that received olaparib $400 \mathrm{mg}$ twice daily (8.4 vs. 4.8 months; HR, 0.35 ; $p<0.001$ ) [32].

In Study 42, a phase II single arm trial, an overall response rate of $34 \%$ was observed in 137 advanced EOC patients who had received three or more lines of chemotherapy and who had a measurable disease at baseline with germline BRCA1/2 mutation $(\mathrm{gBRCA1} / 2 \mathrm{~m})$ with oral $400 \mathrm{mg}$ olaparib twice daily. The median progression-free survival was $6.7 \mathrm{months}$ [33]. Based on this study, the US Food and Drug Administration (FDA) approved olaparib as a treatment for patients with $\mathrm{g} B R C A \mathrm{~m}$ ovarian cancer who had received three or more lines of chemotherapies in 2014 [34].

SOLO-1, an international, randomized, double-blinded, phase III trial, evaluated the efficacy of olaparib as a maintenance therapy in newly diagnosed, advanced, high-grade serous or endometrioid ovarian cancer, primary peritoneal cancer, or tubal cancer with germline or somatic $B R C A$ mutations $(B R C A \mathrm{~m})$. In this study, the risk of disease progression or death was reduced at $70 \%$ with a hazard ratio (HR) of $0.30(p<0.001)$ [35]. In 2018, the US FDA extended the indication of olaparib monotherapy for first-line maintenance treatment in BRCAm advanced ovarian cancer [46].

In the PAOLA-1 trial, patients with newly diagnosed, advanced, high-grade ovarian cancer, having a response after first-line platinum-taxane chemotherapy plus bevacizumab were included, regardless of their BRCA status. In this phase III, randomized, double-blinded trial, the median progression-free survival (PFS) was 22.1 months with olaparib plus bevacizumab as a first-line maintenance, and it was 16.6 months with a placebo plus bevacizumab (HR 0.59, $p<0.001$ ). The treatment benefit was seen in both HRD-positive/BRCAm tumors (HR 0.33) and HRD-positive/BRCA-wild type tumors (HR 0.43) [36]. Based on this result, the US FDA further expanded the approval of olaparib to include its use in combination with bevacizumab for first-line maintenance treatment in HRD-positive advanced ovarian cancer [46].

\section{Rucaparib}

In addition to olaparib, several other PARP inhibitors have had promising results in phase II and phase III trials. ARIEL2, a phase II, open-label trial, evaluated rucaparib in patients with recurrent platinum-sensitive, high-grade, serous or endometrioid ovarian cancers. PFS was significantly longer in the BRCA mutant (12.8 vs. 5.2 months; HR, 0.27 ; $p<0.0001)$ and LOH high (5.7 vs. 5.2 months; HR, 0.62; $p=0.011$ ) subgroups compared with the LOH low subgroup [37].

In the ARIEL3 trial, a phase III, randomized, double-blinded trial in recurrent platinumsensitive high-grade serous or endometrioid ovarian cancers, rucaparib showed significant treatment benefits compared with the placebo in all three biomarker groups that were defined based on the NGS assay that included BRCA-mutant (BRCAm) (PFS 16.6 months vs. 5.4 months, HR $0.23, p<0.0001), B R C A$ wild type (BRCAwt)/loss of heterozygosity (LOH)-high (PFS 9.7 months vs. 5.4 months, HR 0.44, $p<0.0001$ ), and BRCAwt/LOH-low (PFS 6.7 months vs. 5.4 months, HR 0.58, $p=0.0049$ ) [38,39]. Rucaparib has been granted by the FDA for the maintenance of recurrent EOCs in a complete or partial response to platinum-based chemotherapy in 2018.

Niraparib

The efficacy in ovarian cancer treatment of niraparib, a potent PARPi, was mainly evaluated by two randomized, double-blinded, phase III trials, the ENGOT-OV16/NOVA trial and the PRIMA trial, which lead to the FDA approvals of niraparib for the maintenance 
treatment in patients with recurrent, platinum-sensitive EOCs. It was also approved for those with newly diagnosed advanced epithelial ovarian, fallopian tube, or primary peritoneal cancer who are in a complete or partial response to first-line, platinum-based chemotherapy. In the ENGOT-OV16/NOVA trial, 553 platinum-sensitive, recurrent EOC patients were enrolled and randomly assigned to receive niraparib $300 \mathrm{mg}$ or a placebo once daily. In this trial, patients who received niraparib had a significantly longer median PFS in all three subgroups: gBRCAm cohort (21 months vs. 5.5 months, HR $0.27, p<0.001$ ), HRD/gBRCAwt cohort (12.9 months vs. 3.8 months, HR 0.38, $p<0.001$ ), and HR-proficient (HRP)/gBRCAwt cohort (9.3 months vs. 3.9 months, HR 0.45, $p<0.001)$ [40].

The PRIMA study randomized 733 newly diagnosed advanced EOC patients who had complete or partial response to first-line, platinum-based chemotherapy to receive niraparib $300 \mathrm{mg}$ or a placebo once daily as maintenance therapy. Patients in the niraparib group had a significantly longer median PFS in not only the HRD category (21.9 months vs. 10.4 months, HR $0.43, p<0.001)$, but also in overall population (13.8 months vs. 8.2 months, HR $0.62, p<0.001$ ) [41].

The most common grade three or four adverse events (AEs) of PARPis are anemia (17-31\%), fatigue (1.9-9\%), nausea/vomiting (1-8\%), thrombocytopenia, and neutropenia, and they were predominantly found in NOVA and PRIMA trials (28.7-33.8\% and $12.8-19.6 \%$, respectively) $[33,35,36,38-41,47,48]$.

In addition to PARPi monotherapy, there are increasing interests in combination therapy with PARP inhibitors, including an immune checkpoint inhibitor, anti-VEGF $m$ TOR inhibitors, and select trials that are summarized in Table 2.

\subsection{PARP Inhibitors in Endometrial Cancer}

According to The Cancer Genome Atlas data, the HRD phenotype was also recently reported in $25 \%$ of uterine endometrial carcinomas [49]. It occurs largely restricted to non-endometrioid, TP53-mutated endometrial cancers and represents nearly 50\% of the cases [50]. In TP53 wild-type endometrioid carcinoma, the most common molecular alterations, PTEN or ARID1A, have been associated with significant in vitro PARP inhibitor activity [51,52]. Those characteristics increased the interest of $P A R P i$ in uterine cancers. There is an ongoing randomized phase II trial, UTOLA trial, to evaluate olaparib as maintenance therapy in platinum-sensitive advanced uterine cancer. Other ongoing trials are selected and summarized in Table 2. 
Table 2. Select ongoing trials or trials with results pending of PARP inhibitor studies in gynecologic cancers.

\begin{tabular}{|c|c|c|c|c|c|c|}
\hline $\begin{array}{l}\text { ClinicalTrials.gov (Accessed } \\
\text { Date } 6 \text { September 2021) } \\
\text { Identifier/Study }\end{array}$ & Design & Target & $\begin{array}{l}\text { Site of } \\
\text { Cancer }\end{array}$ & Drug & $\begin{array}{l}\text { Estimated } \\
\text { Participants }\end{array}$ & Population \\
\hline NCT02855944/ARIEL4 & Phase III & PARP & OV & Rucaparib vs. Chemotherapy & 345 & Recurrent $B R C A^{m u t}$ HGSOC \\
\hline NCT03326193 & Phase II & PARP/VEGF & $\mathrm{OV}$ & Niraparib, Bevacizumab & 105 & $\begin{array}{l}\text { Advanced EOCs post first-line platinum-based } \\
\text { chemotherapy with bevacizumab }\end{array}$ \\
\hline NCT03278717/ICON9 & Phase III & PARP/VEGF & $\mathrm{OV}$ & Olaparib, Cediranib & 618 & Platinum-sensitive recurrent EOCs \\
\hline $\begin{array}{l}\text { NCT03642132/JAVELIN } \\
\text { OVARIAN PARP } 100\end{array}$ & Phase III & PARP/PD-L1 & OV & Talazoparib, Avelumab & 79 & Advanced EOCs \\
\hline NCT03598270/ANITA & Phase III, RTC & PARP/PD-L1 & OV & Niraparib, Atezolizumab & 414 & Recurrent platinum-sensitive EOCs \\
\hline NCT03522246/ATHENA & Phase III, RTC & PARP/PD-1 & $\mathrm{OV}$ & $\begin{array}{l}\text { Rucaparib } \\
\text { Nivolumab }\end{array}$ & 1000 & $\begin{array}{l}\text { Advanced EOCs with response to first-line } \\
\text { platinum-based chemotherapy }\end{array}$ \\
\hline NCT02953457 & Phase I/II & PARP/PD-L1/CTLA-4 & $\mathrm{OV}$ & $\begin{array}{l}\text { Olaparib } \\
\text { Durvalumab } \\
\text { Tremelimumab }\end{array}$ & 40 & Recurrent $B R C A 1 / 2^{m u t}$ EOCs \\
\hline NCT03737643/DUO-O & Phase III, RTC & PARP/PD-L1/VEGF & $\mathrm{OV}$ & $\begin{array}{l}\text { Olaparib, Durvalumab, } \\
\text { Bevacizumab } \\
\text { Carboplatin+Paclitaxel }\end{array}$ & 1374 & Newly diagnosed advanced EOCs \\
\hline NCT04669002 & Phase IIa/b & PARP/topoisomerase-1 & $\mathrm{OV}$ & Olaparib, EP0057 & 60 & Advanced EOCs with or without previous PARPi \\
\hline NCT03462342/CARPI & Open-label & PARP/ATR & OV & Olaparib, AZD6738 & 86 & Recurrent EOCs \\
\hline NCT04729387/EPIK-O & Phase III & PARP/PI3K & $\mathrm{OV}$ & Olaparib, Alpelisib & 358 & Platinum resistant $\mathrm{HGSOCs}, B R C A^{w t}$ \\
\hline NCT02208375 & Phase Ib & $\mathrm{PARP} / \mathrm{mTORC} / \mathrm{AKT}$ & OV, EM & Olaparib, AZD2014, AZD5363 & 159 & Recurrent EM ca and EOCs \\
\hline NCT03651206/ROCSA & Phase II/III & PARP/PD-1 & OV, EM & Niraparib, TSR-042 & 196 & Recurrent EM or OV carcinosarcoma \\
\hline NCT04716686 & Open-label & PARP & EM & Niraparib & 83 & Recurrent EM serous carcinoma \\
\hline NCT03660826 & Phase II & PARP/PD-L1/VEGF & EM & $\begin{array}{l}\text { Olaparib, Cediranib, } \\
\text { Durvalumab, Capivasertib }\end{array}$ & 120 & Recurrent/persistent/metastatic endometrial cancer \\
\hline NCT03951415/DOMEC & Phase II & PARP/PD-L1 & EM & Olaparib, Durvalumab & 55 & $\begin{array}{l}\text { Advanced/recurrent/refractory/metastatic EMCA, } \\
\text { including carcinosarcoma }\end{array}$ \\
\hline NCT03694262/EndoBARR & Phase II & PARP/PD-1/VEGF & EM & $\begin{array}{l}\text { Rucaparib, } \\
\text { Atezolizumab, Bevacizumab }\end{array}$ & 30 & Recurrent or progressive EMCA \\
\hline
\end{tabular}




\section{Mismatch Repair (MMR)/Microsatellite Instability (MSI)}

\subsection{MMR Deficiency (dMMR) and MSI in Gynecologic Cancer}

DNA mismatch repair (MMR) plays a key role in genomic stability by identifying and repairing base-base mismatches and insertion/deletion mismatches during DNA replication and recombination [53]. Microsatellite sequences are segments of repeated DNA (usually 10-60 base pair) composed of several base pairs (usually 1-6 base pair) that repeat sequentially $[54,55]$. These DNA segments are susceptible to mutations since they are prone to DNA polymerase pausing and slippage during DNA replication due to their repetitive nature [54,56]. MMR, as a part of the DNA repair system, maintains the repeat count of microsatellites during cell division by recognizing the newly replicated DNA and repairing the DNA mutations $[53,57]$. Mismatch repair deficiency (dMMR) leads to cells being unable to regulate the lengths of their microsatellites, which results in microsatellite instability (MSI) and malignancies, including gynecologic cancers $[55,58]$.

MMR deficiencies are known to occur through inherited germline MMR pathway mutations or somatic mutations. Lynch syndrome, an inherited disease with the mutation of the MMR genes (MLH1, MSH2, MSH6, or PMS2) or deletion of the stop codon of the EPCAM genes, is one of the most prevalent hereditary cancer-prone syndromes. Besides colorectal cancer, Lynch syndrome is associated with increased frequencies of cancers of the endometrium, stomach, small bowel, hepatobiliary system, upper urologic tract, and ovary $[59,60]$. In germline dMMR population, the cumulative endometrial cancer risk at 70 years is highest in $M L H 1$ mutations (34-54\%), followed by MSH2 (21-51\%), MSH6 (16-49\%), and PMS2 (13-24\%) mutations. The cumulative ovarian cancer is highest in MSH2 mutations (15\%), followed by MLH1 mutations (11\%) [58,61]. Epigenetic alterations, such as hypermethylation of the MLH1 promoter, epigenetic inactivation of $M S H 2$, or downregulation of MMR genes by miRNAs, can suppress transcription and interfere with the expression of MMR genes and cause dMMR [58,62-64]. Hypermethylation of the MLH1 promoter is the most common cause of sporadic dMMR/MSI [58].

dMMR was found in over $17-33 \%$ of endometrial cancers, $3.5 \%$ of uterine carcinosarcomas, and in $2.6 \%$ of cervical squamous cell carcinomas and endocervical adenocarcinomas [55]. dMMR is found in approximately $10-12 \%$ of epithelial ovarian cancers with a predominance in endometrioid $(19.2 \%)$, mucinous $(16.9 \%)$, and clear cell (11.5\%) histology, whereas the incidence of dMMR in serous cancers has been reported to be 1-8\% [65-67]. The most frequent mutations were MSH2 (47\%) and MLH1 (38\%) in women with Lynch syndrome and who were diagnosed with epithelial ovarian cancer with a favorable 10-year overall survival [68]. Undifferentiated and dedifferentiated endometrial carcinoma, an undifferentiated carcinoma mixed with differentiated endometrioid carcinoma, was also reported with approximately $50 \%$ of MMR deficiency [69].

\subsection{Detection of $M S I$}

There are several clinically available MSI detection methods, including NGS with the accuracy of 92-94.6\%, Fluorescent multiplex PCR and CE (gold standard) with the accuracy of $100 \%$, immunochemistry (IHC) stain of MMR proteins with the accuracy of $89-95 \%$, and smMIPs with the accuracy of 95.8\% [70-74]. High microsatellite instability (MSI-H), low microsatellite instability (MSI-L), and microsatellite stability (MSS) are classified according to the frequency of MSI. MSI-H is historically defined as instability in two or more of the five markers in the Bethesda reference panel (BAT-25, BAT-26, D2S123, D5S346 and D17S250) or, as detected by PCR, whereas instability in only one marker is considered to be MSI-L [75,76]. In more expanded microsatellite panels, MSI-H is defined as instability in more than $30-40 \%$ of the markers and MSI-L as alteration in 10-30\% of the markers [76,77]. In colorectal cancers, the concordance between PCR and IHC was as high as $96 \%$, but a much lower concordance of $68 \%$ was reported in ovarian cancer [58]. Thus, the detection methods and panels in gynecologic cancers need to be further evaluated. 


\subsection{Targeting Dmmr/Msi-High Gynecologic Cancer}

Mismatched repair-deficient tumors have high MSI and harbor 10-100 times more mutations that encode potential neoantigens than MMR-proficient tumors [78]. Expression of programmed death ligand 1 (PD-L1), a tumor immune checkpoint, on the cell membrane of dMMR tumors has been reported [79]. Furthermore, increased CD8+ tumor-infiltrating lymphocytes (TILs) and overexpression of programmed death 1 (PD-1) on the TILs and peritumoral lymphocytes have been also found [79]. Increased CD8+ TILs, higher CD8+/CD4+ ratio, and higher PD-1 positive TILs were found in ovarian clear cell carcinoma with MSI, which may have benefitted from immunotherapies [80]. Those immunogenic signatures in dMMR tumors render them susceptible to immune checkpoint blockades that reactivate $\mathrm{T}$ cells for an antitumor response.

Anti-PD-1/PD-L1 immunotherapy has been shown to be effective in a wide range of cancers, including ovarian cancers, cervical cancer, and endometrial cancer. Pembrolizumab (Keytruda, Merck \& Co., NJ, USA.), a humanized immunoglobulin G4 monoclonal antibody that blockades $P D-1$ on lymphocytes that allow the reactivation of $\mathrm{T}$ cell-mediated tumor killing, received accelerated approval by the US FDA in 2017 for the treatment of adult and pediatric patients with unresectable or metastatic MSI-H/dMMR solid tumors that have progressed after prior standard treatment and have no satisfactory alternative treatment options [81,82].

In KEYNOTE-158, a nonrandomized, open-label, multisite phase II trial, pembrolizumab (200 mg every 3 weeks, for 35 cycles) showed an objective response rate (ORR) of 57.1\% with a median PFS of 25.7 months in 49 MSI-H/dMMR endometrial cancer patients (8 with complete response (CR) and 20 with partial response (PR)) and the ORR was $33.3 \%$ with a median PFS of 2.3 months in 15 MSI-H/dMMR ovarian cancer patients (three with CR and two with PR) [83].

In the KEYNOTE-146/Study 111 trial, pembrolizumab was combined with Lenvatinib (Lenvima, Eisai, Tokyo, Japan), an oral multikinase inhibitor that targets vascular endothelial growth factor receptors (VEGF) 1-3, fibroblast growth factor receptors (FGFR) $1-4$, platelet-derived growth factor (PDGF) $-\alpha$, RET, and KIT for the treatment of previously treated endometrial cancer patients. A total of 108 patients were enrolled in this phase $\mathrm{Ib} / \mathrm{II}$ study. In 11 patients with dMMR/MSI-H tumors, the ORR was $63.6 \%$, whereas the ORR was $36.2 \%$ in MMR-proficient (pMMR)/MSS tumors [84], which led to an accelerated approval by the US FDA of this combination to be used in pMMR endometrial cancer.

\section{Tumor Suppressor Gene TP53}

\subsection{Tumor Suppressor p53 in Gynecologic Cancers}

Tumor suppressor gene TP53 is the most frequently mutated gene in high-grade serous adenocarcinoma of the ovary and the endometrium, which is found in $96 \%$ of ovarian highgrade serous carcinoma and in more than $90 \%$ of endometrial serous adenocarcinoma [8,9]. Tumor suppressor $p 53$ functions as a major barrier to neoplastic transformation. As the principal cellular responder to stress signals, including oncogene activation, DNA damage, and hypoxia, $p 53$ induces cell cycle arrest to keep genomic stability or apoptosis, senescence, or ferroptosis to eliminate abnormal or unrecoverable cells $[85,86]$. The majority of TP53 mutations are missense mutations that produce a single amino acid substitution in the protein's DNA-binding domain. Mutant $p 53$ may interact with many transcription factors such as $p 63, p 73, N F-k B, A T M$, and $S M A D s$, altering the transcription, cell cycle, apoptosis, and metabolism of cancer cells, resulting in oncogenic gain-of-function. These changes lead to genetic instability, proliferation, metastasis, and chemoresistance. The missense mutations are divided into two categories: DNA contact mutations such as R248Q and $\mathrm{R} 273 \mathrm{H}$, and conformational mutations such as R249S, G245S, R175H, and R282W. These six hotspots account for nearly one third of all $p 53$ mutations and may be considered as targets for cancer treatment. 


\subsection{Treatment Strategies in Cancer Harboring TP53 Mutation}

\subsubsection{Small-Molecule-Based Therapy Targeting Mutant p53}

APR-246 (PRIMA-1MET), a methylated analogue of PRIMA-1, is a prodrug that is converted to the active compound methylene quinuclidinone that binds to cysteine residues in mutant p53 and restores its wild-type function [86,87]. APR-246 showed synergistic effects with cisplatin, carboplatin, doxorubicin, or gemcitabine, in ovarian cancer cell lines and re-sensitized platinum-resistant ovarian cancer cells [87]. There are several phase I/II trials of APR-246 in combination with carboplatin or doxorubicin in high grade serous ovarian cancer, and the results are pending (Table 3).

Adavosertib (MK-1775), a potent, small-molecule WEE1 kinase inhibitor, showed an antitumor effect with the combination of chemotherapy and radiotherapy in preclinical studies $[88,89]$. Since p53 is mainly responsible for the G1-S cell cycle arrest, p53 mutant cancer cells are more dependent on G2-M checkpoints to maintain genomic stability in the presence of DNA damage. WEE1 is a tyrosine kinase that is involved in DNA damage induced G2-M cell cycle arrest by regulating CDK1 activity. Inhibition of WEE1, combined with DNA-damaging agents, causes the inactivation of the G2-S checkpoint, leading to unscheduled mitotic entry of cells without completion of DNA repair and replication, and it results in mitotic catastrophe and cell death in p53 mutant-harboring tumor cells [86,90]. In a phase II randomized, double-blinded trial, a total of 121 patients with TP53-mutated, platinum-sensitive recurrent ovarian cancer were randomized to an oral adavosertib $225 \mathrm{mg}$ twice daily for 2.5 days every 21 days or a placebo plus carboplatin and paclitaxel. In this phase II trial, the median progression-free survivals were 7.9 and 7.3 months for the adavosertib group and the placebo group, respectively, $\mathrm{HR}, 0.63 ; p=0.08$ ) [90]. In another phase II randomized, double-blinded trial, patients with recurrent platinum-resistant or platinum-refractory high-grade serous ovarian cancer were treated with gemcitabine and adavosertib $175 \mathrm{mg}$ or an identical placebo once daily on days $1,2,8,9,15$, and 16 , in 28-day cycles under disease progression [91]. Whole-exome sequencing showed 95\% and 100\% positive of TP53 mutation in the adavosertib group and the placebo group, respectively. In this trial, patients who received adavosertib plus gemcitabine had longer PFS compared to patients with placebo plus gemcitabine (4.6 vs. 3.0 months; $\mathrm{HR}, 0.55 ; p=0.015$ ) and a longer median OS (11.4 vs. 7.2 months; HR, 0.56; $p=0.017$ ). The most frequent grade three or more adverse events were neutropenia, anemia, and thrombocytopenia in these two trials [90,91]. A phase II trial of adavosertib in recurrent uterine serous carcinoma also showed substantial activity (ORR 29.4\%, median PFS 6.1 months) [92]. There are several ongoing trials of adavosertib in combination with systemic chemotherapy or PARPi in gynecologic cancers, and they are listed in Table 3.

\subsubsection{Adoptive Cellular Therapy Targeting p53 Neoantigens}

Adoptive cell therapy is a personalized immunotherapy that transplants autologous or allogeneic immune cells, including tumor-infiltrating lymphocytes (TIL), and immune cells with or without genetic modifications, for cancer treatment. Autologous TIL has shown a durable response in patients with solid tumors, including melanoma, breast, and colon cancers. TILs generate adaptive immune response based on recognition of unique tumor neoantigen through immunogenic T-cell receptors. TILs from resected metastatic ovarian cancers that recognized two TP53 mutation hotspots, Y220C and G245S, were identified in a recent study [93]. Beyond TIL, after in vitro stimulation with p53 neoantigens, the selected and expanded CD4+ and CD8+ antigen experienced memory T cells from peripheral blood lymphocytes of patients with a mutated TP53 tumor, which also showed T-cell responses to the mutant p53 [94]. These preclinical studies showed a new treatment strategy targeting TP53 mutation and possibilities of clinical benefits in cancers with TP53 mutations, such as high grade serous ovarian cancer. 
Table 3. Ongoing trials of targeted therapy in ARID1A and other genetic alterations in gynecologic cancers.

\begin{tabular}{|c|c|c|c|c|c|c|}
\hline $\begin{array}{l}\text { ClinicalTrials.gov (Accessed } \\
\text { Date } 6 \text { September 2021) } \\
\text { Identifier/Study }\end{array}$ & Design & $\begin{array}{l}\text { Associated Genetic } \\
\text { Alteration }\end{array}$ & Target & Drug & $\begin{array}{l}\text { Estimated } \\
\text { Participants }\end{array}$ & Population \\
\hline NCT04104776 & Phase I/II & ARID1A $A^{\text {mut }}$ & $\mathrm{EZH} 2$ & CPI-0209 & 268 & OCCC/EMCA, ARID1A $A^{m u t}$ \\
\hline NCT05023655 & Phase II & ARID1A $A^{\text {mut }}$ & $\mathrm{EZH} 2$ & Tazemetostat & 40 & Solid tumors, ARID1 $A^{m u t}$ \\
\hline NCT04493619 & Phase Ib/IIa & ARID1 $A^{\text {mut }}$ & BRD4 & PLX2853 +/ - Carboplatin & 67 & $\begin{array}{l}\text { PLX2853 monotherapy: ARID1A }{ }^{\text {mut }} \text { advanced } \\
\text { gynecologic cancers } \\
\text { PLX2853+carboplatin: platinum-resistant EOC }\end{array}$ \\
\hline NCT02059265 & Phase II & BAF250a ${ }^{m u t}$ & SFK & Dasatinib & 35 & $\begin{array}{l}\text { Recurrent or persistent EOCs and endometrial } \\
\text { clear cell carcinoma }\end{array}$ \\
\hline NCT02730923/VICTORIA & Phase I/II & PTEN $^{\text {mut }}$ & mTORC1/mTORC2 & $\begin{array}{l}\text { AZD2014 } \\
\text { Anastrozole }\end{array}$ & 72 & $\begin{array}{l}\text { Metastatic hormone receptor-positive } \\
\text { EM adenocarcinoma }\end{array}$ \\
\hline NCT04931342 & Phase II & $\begin{array}{l}\text { AKT }^{m u t} \\
\text { BRAF/MEK } \\
\text { HER2 amplification } \\
\text { or mutations }\end{array}$ & $\begin{array}{l}\text { AKT } \\
\text { BRAF/MEK } \\
\text { HER2 }\end{array}$ & $\begin{array}{l}\text { Ipatasertib } \\
\text { Cobimetinib } \\
\text { Trastuzumab entansine } \\
\text { Atezolizumab + Bevacizumab }\end{array}$ & 200 & $\begin{array}{l}\text { Persistent or recurrent epithelial ovarian cancer, } \\
\text { fallopian tube, or primary peritoneal tumors. }\end{array}$ \\
\hline NCT04729387 & Phase III & No BRCA ${ }^{m u t}$ & PARP/PIK3CA & $\begin{array}{l}\text { Alpelisib+olaparib } \\
\text { vs Paclitaxel or Pegylated liposomal } \\
\text { doxorubicin (PLD) }\end{array}$ & 326 & $\begin{array}{l}\text { Platinum resistant or refractory high-grade serous } \\
\text { ovarian cancer, with no germline BRCA mutation }\end{array}$ \\
\hline NCT02098343 & Phase Ib/II & p53 & p53 & Carboplatin with or without APR-246 & 200 & $\begin{array}{l}\text { Recurrent platinum-sensitive high-grade serous } \\
\text { ovarian cancer }\end{array}$ \\
\hline NCT02465060 & Phase II & MATCH screening & $\begin{array}{l}\text { Wee1, EGFR } \\
\text { MAPK } \\
\text { BRAF/MEK } \\
\text { AKT } \\
\text { PI3K } \\
\text { NTRK } \\
\text { HER2 PIK3CA } \\
\text { HER2 } \\
\text { ALK } \\
\text { PD1 } \\
\text { CDK4/6 } \\
\text { ERK } \\
\text { Hedgehog }\end{array}$ & $\begin{array}{l}\text { Adavosertib; Afatinib dimaleate; } \\
\text { Binimetinib; Capivasertib; Copanlisib; } \\
\text { Crizotinib; Dabrafenib; Dasatinib; } \\
\text { Defactinib; Erdafitinib; Ipatasertib; } \\
\text { Larotrectinib; Nivolumab; Osimertinib; } \\
\text { Palbociclib; Pertuzumab } \\
\text { GSK2636771B; Relatlimab } \\
\text { Sapanisertib; Sunitinib Malate } \\
\text { Taselisib; Trametinib } \\
\text { Trastuzumab; Trastuzumab Emtansine; } \\
\text { Ulixertinib; Vismodegib }\end{array}$ & 6420 & $\begin{array}{l}\text { Advanced refractory solid tumors (including } \\
\text { ovarian, cervical cancer and corpus cancer), } \\
\text { Lymphomas, or Multiple Myeloma }\end{array}$ \\
\hline
\end{tabular}




\section{Genetic Alterations Associated with Virus Infection}

\subsection{HPV as an Initiating Agent for Cervical Carcinogenesis}

There is strong epidemiological and molecular biological evidence indicating that HPV plays a crucial role in the etiology of cervical cancer [95]. The HPV oncoproteins, E6 and E7, inhibit p53 and pRb, respectively, causing alterations of DNA repair, apoptosis, and angiogenesis, which eventually result in carcinogenesis [96,97]. High-risk HPV types also induce mitotic defects and genomic instability and cause specific mutation signatures, primarily the apolipoprotein B mRNA editing catalytic polypeptide-like (APOBEC) mutation $[98,99]$.

\subsection{HPV Integration Site}

Recent studies have reported that the most frequent integration sites of HPV were in the MACROD2, MIPOL1/TTC6, TP63, ERBB2, KLF12, and RAD51B gene by next-generation sequencing (NGS) in 272 Cervical cancer patients from the BioRAIDs study [NCT02428842] [4]. $\mathrm{HPV}$ integration sites that are within or in close proximity to several fragile sites in the $M Y C, E R B B 2, T P 63, F A N C C, R A D 51 B$, and CEACAM5 may trigger genome instability and the nearest copy number amplification as well as increased expression of adjacent genes [100].

\subsection{Copy Number Alterations in HPV-Related Cervical Carcinoma}

HPV integration events affect all chromosomes, including some previously described at 3q26.31 (TERC, MECOM), 3q28 (TP63), 8q24.21 (MYC, PVT1), 11q22.1 (YAP1, BIRC2, $B I R C 3)$, and 17q12 (ERBB2) in cervical cancer and recurrent focal amplification events have been identified at 7p11.2 (EGFR), 9p24.1 (CD274, PDCD1LG2), 13q22.1 (KLF5), and 16p13.13 (BCAR4). In addition to previously identified deletions, at 4q35.2 (FAT1) and 10q23.31 $(P T E N)$ and recurrent deletions were identified at 3p24.1 (TGFBR2) and 18q21.2 (SMAD4). Among those, ERBB2, CD274 (PD-L1), and PDCD1LG2 (PD-L2) had amplifications that highlight the potential for clinical trials of ERBB2 inhibitors and immunotherapeutic strategies for a subset of cervical cancers $[10,101]$.

\section{Other Druggable Targets Associated with Genetic Alterations in Gynecologic Cancers \\ 6.1. PI3K/AKT/mTOR Pathway}

Somatic loss of phosphatase and tensin homolog (PTEN) is one of the most common genomic aberrations in endometrioid endometrial cancer, which were found in $43-46 \%$ of cases $[9,102,103]$. Homozygous PTEN deletion, caused by focal deletion at 10q23.31, has been found in $7 \%$ of high-grade serous ovarian cancers and is associated with downregulation of PTEN at the mRNA level [8]. In cervical cancer, aberrations in PIK3CA also tended to co-occur with PTEN somatic mutations, suggesting potential therapeutic benefits from PI3K-pathway-targeting agents [9].

PTEN alterations in cervical cancer are around $8 \%$ and are mostly due to missense and nonsense mutations [103]. As a tumor suppressor, PTEN inhibits the activation of the cell's pro-survival signaling pathway, phosphoinositide 3-kinase (PI3K)/AKT pathway, which is important in initiation and progression of endometrial cancer [104,105]. PTEN plays a fundamental role in the maintenance of chromosomal stability through the physical interaction with centromeres and control of DNA repair, and it regulates the expression of RAD51, a key protein of the HR pathway [106]. Inhibition of PI3K in PTEN mutated cells has been shown to reduced RAD51 levels and sensitize these cells to PARPi [107].

Moreover, cases of EMSY amplification and PTEN homozygous deletions, which may cause HRD, and the CCNE1 amplifications, which are associated with HR proficiency, were identified [26]. PTEN deficiency is also thought to be associated with transcriptional downregulation of RAD51, which may have the potential to be treated with PARP inhibition, though some studies showed that PTEN and RAD51 are independent [108]. Mutation of 
RTK/RAS-PI3K pathway was found to be related to the resistance of BETi treatment in cancers, including ovarian cancers [109].

Monotherapy with PI3K/AKT/mTOR inhibitors in gynecologic cancers, however, has been shown to have a limited clinical benefit, and no drug is approved by the US FDA in gynecologic cancer currently [110]. Since activation of AKT is shown to be related to PARPi resistance in recent studies, there are some ongoing trials trying to combine $\mathrm{PI} 3 K / \mathrm{AKT} / \mathrm{mTOR}$ inhibitors and PARPi in gynecologic cancers [111] (Table 2).

\subsection{ARID1A}

BRG1-associated factor (BAF) is an important tumor suppressor and the most frequently disrupted subunit of ARID1A [112]. This is a component of the BAF/PBAF complex, which involves transcriptional effects in polycomb silencing, DNA accessibility for transcription, and splicing patterns, as well as DNA repair and maintenance of chromatin topology and 3D architecture [113].

ARID1A have since been observed at high frequency in a number of studies, including uterine and ovarian clear cell carcinoma (46-57\%), ovarian endometrioid carcinoma $(30 \%)$, and uterine endometrioid carcinoma (47-60\%) [113-116]. Some studies showed that MMR deficiency is associated with the loss of ARID1A expression in ovarian clear cell carcinoma [117]. BRD inhibition showed promising anticancer effects in some preclinical studies in clear cell carcinoma models [118]. However, phase I studies of BRD inhibitors showed dose-limited toxicities, including nausea, thrombocytopenia, and extended fatigue, which brought the obstacles for clinical use [119]. Studies showed that the loss of ARID1A increased microsatellite instability through deficient recruitment of $M M R$ genes, which enhanced mutational burden and sensitized tumors to PD-L1 blockade [112,120].

In ovarian cancer, mutations of $A R I D 1 A$ are frequently found with activating mutations of PI3K [113]. Activating mutations of PI3K may lead to altered BAF localization or function. In the mouse model, ovarian tumors with similar features to ovarian clear cell carcinoma were only developed when with ARID1A/PI3K double mutations, but not with only a single ARID1A or PI3K mutation, suggesting the effects the cooperation of these two genes have in cancer [121]. Recent reports suggest new approaches for targeting tumors with altered $B A F / P B A F$ complexes based on synthetic lethality. For example, tumors with ARID1A mutations often depend on ARID1B. Targeting these genetic dependencies represents a novel strategy to attack these tumors.

Inhibition of BRD4 may cause a synergy effect with PARPi, which makes it a therapeutic target for tumors that harbor ARID1A alterations [122]. Cyclin-E1 (CCNE1) gene amplification is presented in 15\% of ovarian cancers [8]. Cyclin-E1 (CCNE1) is found as a potential therapeutic target for ARID1A-mutated ovarian clear cell carcinoma through synthetic lethality [116]. CCNE1 gain and RB1 loss discriminate patients with tumors extremely sensitive to platinum retreatment $[123,124]$. There are some ongoing trials that target ARID1A-associated cancers (Table 3).

\subsection{Potential Targets in DNA Damage Repair and Synthetic Lethality beyond PARP Inhibitors}

The encouraging results of PARPis led to an increasing interest in cancer research focused on targeting various pathways involved in DNA damage repair by synthetic lethal approaches. The ataxia telangiectasia and Rad3-related (ATR) inhibitors, DNA-dependent protein kinase (DNA-PK) inhibitors, WEE1 inhibitors, and checkpoint kinase 1/2 (CHK1/2) inhibitors have shown promising clinical results recently, and a number of ongoing trials are focusing on gynecologic cancers [25,125] (Tables 2 and 3). On the other hand, mutations of CDK12 were found in 3\% of EOCs. As one of the nine significantly mutated genes in ovarian cancer, CDK12 involves the transcription of BRCA1 and other DNA repair genes. Disabling of CDK12 shows reduced BRCA1 levels, impaired HR repair, and increased sensitivity to the PARP inhibitor, and combination therapy with CDK12 inhibitor and PARPi is a potential treatment to overcome resistance of PARPi [126]. 


\subsection{Other Druggable Targets That Are under Development}

A prospective phase II trial revealed that trastuzumab in combination with paclitaxel and carboplatin significantly prolonged PFS more than chemotherapy alone in 41 stage III, IV HER2/neu over-expressed serous endometrial cancer patients (17.9 months vs. 9.3 months, HR 0.40, $p=0.013$ ) [127]. However, there is no phase III study ongoing after the initial success, probably because of the rarity of such a tumor. Only a biomarker-driven study involving trastuzumab entansine is ongoing (Table 3). the enhancer of zeste 2 (EZH2) is a key epigenetic regulator of gene expression and is frequently overexpressed in cancers, including ovarian cancer and endometrial cancer $[128,129]$. MAPK1 mutations and the known role of the MAPK signaling pathway in cancer suggest the possibility that the mutant MAPK1 may exert oncogenic activity in cervical cancer [130]. Therapeutic agents for CCNE1, EZH2, MAPK1, and the other identified variants, including the FGFR family, MYC, MET, KRAS, and cell cycle checkpoints, are currently under investigation in active and ongoing clinical trials (Table 3).

\section{Conclusions}

The most prominent progress in gynecologic cancers is the clinical efficacy of PARPi; their remarkable benefits in reducing HRs of progression or death from BRCA 1/2m ovarian cancer is breath-taking. Immune checkpoint inhibition in combination with targeted therapy is also promising. New cancer treatments that identify and target pathogenic abnormalities of genes will make many breakthroughs in the years to come.

Author Contributions: Writing-original draft preparation, Y.-H.T., C.-Y.L. and C.-H.L.; writingreview and editing, Y.-H.T., C.-Y.L. and C.-H.L. All authors have read and agreed to the published version of the manuscript.

Funding: This research was funded by Chang Gung Foundation (CMRPG3E0661 2 and CMRPG3K1051).

Conflicts of Interest: The authors declare no conflict of interest.

$\begin{array}{ll}\text { Abbreviations } \\ \text { AE } & \text { Adverse event } \\ \text { BID } & \text { Twice daily } \\ \text { CR } & \text { Complete response } \\ \text { DSB } & \text { Double-strand break } \\ \text { EM } & \text { Endometrium } \\ \text { EMCA } & \text { Endometrial cancer } \\ \text { EOC } & \text { Epithelial ovarian cancer } \\ \text { HGOC } & \text { High-grade ovarian cancer } \\ \text { HGSOC } & \text { High-grade serous ovarian cancer } \\ \text { HR } & \text { Hazard ratio } \\ \text { HRD } & \text { Homologous-recombination deficiency } \\ \text { HRP } & \text { Homologous-recombination proficiency } \\ \text { LOH } & \text { Loss of heterozygosity } \\ \text { NGS } & \text { Next-generation sequencing } \\ \text { OCCC } & \text { Ovarian clear cell carcinoma } \\ \text { ORR } & \text { Overall response rate } \\ \text { PARP } & \text { Poly(ADP-ribose) polymerase } \\ \text { PD-L1 } & \text { Programmed death ligand 1 } \\ \text { PFS } & \text { Progression-free survival } \\ \text { PR } & \text { Partial response } \\ \text { RCT } & \text { Randomized control trial } \\ \text { TIL } & \text { Tumor-infiltrating lymphocyte }\end{array}$




\section{References}

1. Sung, H.; Ferlay, J.; Siegel, R.L.; Laversanne, M.; Soerjomataram, I.; Jemal, A.; Bray, F. Global Cancer Statistics 2020: GLOBOCAN Estimates of Incidence and Mortality Worldwide for 36 Cancers in 185 Countries. CA Cancer J. Clin. 2021, 71, 209-249. [CrossRef]

2. Lheureux, S.; Gourley, C.; Vergote, I.; Oza, A.M. Epithelial ovarian cancer. Lancet 2019, 393, 1240-1253. [CrossRef]

3. Lu, K.H.; Broaddus, R.R. Endometrial Cancer. N. Engl. J. Med. 2020, 383, 2053-2064. [CrossRef] [PubMed]

4. Kamal, M.; RAIDs Consortium; Lameiras, S.; Deloger, M.; Morel, A.; Vacher, S.; Lecerf, C.; Dupain, C.; Jeannot, E.; Girard, E.; et al. Human papilloma virus (HPV) integration signature in Cervical Cancer: Identification of MACROD2 gene as HPV hot spot integration site. Br. J. Cancer 2021, 124, 777-785. [CrossRef] [PubMed]

5. $\quad$ Burger, R.A.; Brady, M.F.; Bookman, M.A.; Fleming, G.F.; Monk, B.J.; Huang, H.; Mannel, R.S.; Homesley, H.D.; Fowler, J.; Greer, B.E.; et al. Incorporation of Bevacizumab in the Primary Treatment of Ovarian Cancer. N. Engl. J. Med. 2011, 365, 2473-2483. [CrossRef]

6. Chan, J.K.; Brady, M.F.; Penson, R.T.; Huang, H.; Birrer, M.J.; Walker, J.L.; DiSilvestro, P.A.; Rubin, S.C.; Martin, L.P.; Davidson, S.A.; et al. Weekly vs. Every-3-Week Paclitaxel and Carboplatin for Ovarian Cancer. N. Engl. J. Med. 2016, 374, 738-748. [CrossRef] [PubMed]

7. Tewari, K.S.; Burger, R.A.; Enserro, D.; Norquist, B.M.; Swisher, E.M.; Brady, M.F.; Bookman, M.A.; Fleming, G.F.; Huang, H.; Homesley, H.D.; et al. Final Overall Survival of a Randomized Trial of Bevacizumab for Primary Treatment of Ovarian Cancer. J. Clin. Oncol. 2019, 37, 2317-2328. [CrossRef]

8. The Cancer Genome Atlas Research Network. Integrated genomic analyses of ovarian carcinoma. Nature 2011, 474, 609-615. [CrossRef] [PubMed]

9. The Cancer Genome Atlas Research Network; Kandoth, C.; Schultz, N.; Cherniack, A.D.; Akbani, R.; Liu, Y.; Shen, H.; Robertson, A.G.; Pashtan, I.; Shen, R.; et al. Integrated genomic characterization of endometrial carcinoma. Nature 2013, 497, 67-73. [CrossRef]

10. The Cancer Genome Atlas Research Network. Integrated genomic and molecular characterization of cervical cancer. Nature 2017, 543, 378-384. [CrossRef]

11. Konstantinopoulos, P.A.; Norquist, B.; Lacchetti, C.; Armstrong, D.; Grisham, R.N.; Goodfellow, P.J.; Kohn, E.C.; Levine, D.A.; Liu, J.F.; Lu, K.H.; et al. Germline and Somatic Tumor Testing in Epithelial Ovarian Cancer: ASCO Guideline. J. Clin. Oncol. 2020, 38, 1222-1245. [CrossRef] [PubMed]

12. Tan, D.; Rothermundt, C.; Thomas, K.; Bancroft, E.; Eeles, R.; Shanley, S.; Ardern-Jones, A.; Norman, A.; Kaye, S.B.; Gore, M.E. "BRCAness" Syndrome in Ovarian Cancer: A Case-Control Study Describing the Clinical Features and Outcome of Patients with Epithelial Ovarian Cancer Associated WithBRCA1andBRCA2Mutations. J. Clin. Oncol. 2008, 26, 5530-5536. [CrossRef] [PubMed]

13. Cass, I.; Baldwin, R.L.; Varkey, T.; Moslehi, R.; Narod, S.A.; Karlan, B.Y. Improved survival in women withBRCA-associated ovarian carcinoma. Cancer 2003, 97, 2187-2195. [CrossRef] [PubMed]

14. Rubin, S.C.; Benjamin, I.; Behbakht, K.; Takahashi, H.; Morgan, M.A.; Livolsi, V.A.; Berchuck, A.; Muto, M.G.; Garber, J.E.; Weber, B.L.; et al. Clinical and Pathological Features of Ovarian Cancer in Women with Germ-Line Mutations ofBRCA1. N. Engl. J. Med. 1996, 335, 1413-1416. [CrossRef]

15. Vencken, P.M.L.H.; Kriege, M.; Hoogwerf, D.; Beugelink, S.; van der Burg, M.E.L.; Hooning, M.J.; Berns, E.M.; Jager, A.; Collée, M.; Burger, C.W.; et al. Chemosensitivity and outcome of BRCA1- and BRCA2-associated ovarian cancer patients after first-line chemotherapy compared with sporadic ovarian cancer patients. Ann. Oncol. 2011, 22, 1346-1352. [CrossRef]

16. Oza, A.M.; Tinker, A.V.; Oaknin, A.; Shapira-Frommer, R.; McNeish, I.; Swisher, E.M.; Ray-Coquard, I.; Bell-McGuinn, K.; Coleman, R.L.; O'Malley, D.M.; et al. Antitumor activity and safety of the PARP inhibitor rucaparib in patients with high-grade ovarian carcinoma and a germline or somatic BRCA1 or BRCA2 mutation: Integrated analysis of data from Study 10 and ARIEL2. Gynecol. Oncol. 2017, 147, 267-275. [CrossRef]

17. Takaya, H.; Nakai, H.; Takamatsu, S.; Mandai, M.; Matsumura, N. Homologous recombination deficiency status-based classification of high-grade serous ovarian carcinoma. Sci. Rep. 2020, 10, 2757. [CrossRef]

18. Bajrami, I.; Frankum, J.R.; Konde, A.; Miller, R.E.; Rehman, F.L.; Brough, R.; Campbell, J.; Sims, D.; Rafiq, R.; Hooper, S.; et al. Genome-wide Profiling of Genetic Synthetic Lethality Identifies CDK12 as a Novel Determinant of PARP1/2 Inhibitor Sensitivity. Cancer Res. 2014, 74, 287-297. [CrossRef]

19. How, J.; Jazaeri, A.; Fellman, B.; Daniels, M.; Penn, S.; Solimeno, C.; Yuan, Y.; Schmeler, K.; Lanchbury, J.; Timms, K.; et al. Modification of Homologous Recombination Deficiency Score Threshold and Association with Long-Term Survival in Epithelial Ovarian Cancer. Cancers 2021, 13, 946. [CrossRef]

20. Lord, C.J.; Ashworth, A. PARP inhibitors: Synthetic lethality in the clinic. Science 2017, 355, 1152-1158. [CrossRef]

21. Gibson, B.A.; Kraus, W.L. New insights into the molecular and cellular functions of poly(ADP-ribose) and PARPs. Nat. Rev. Mol. Cell Biol. 2012, 13, 411-424. [CrossRef] [PubMed]

22. Krishnakumar, R.; Kraus, W.L. The PARP Side of the Nucleus: Molecular Actions, Physiological Outcomes, and Clinical Targets. Mol. Cell 2010, 39, 8-24. [CrossRef]

23. Bai, P.; Cantó, C. The Role of PARP-1 and PARP-2 Enzymes in Metabolic Regulation and Disease. Cell Metab. 2012, 16, 290-295. [CrossRef]

24. George, A.; Kaye, S.; Banerjee, S. Delivering widespread BRCA testing and PARP inhibition to patients with ovarian cancer. Nat. Rev. Clin. Oncol. 2016, 14, 284-296. [CrossRef] [PubMed] 
25. Topatana, W.; Juengpanich, S.; Li, S.; Cao, J.; Hu, J.; Lee, J.; Suliyanto, K.; Ma, D.; Zhang, B.; Chen, M.; et al. Advances in synthetic lethality for cancer therapy: Cellular mechanism and clinical translation. J. Hematol. Oncol. 2020, 13, 1-22. [CrossRef]

26. Konstantinopoulos, P.A.; Ceccaldi, R.; Shapiro, G.I.; D'Andrea, A.D. Homologous Recombination Deficiency: Exploiting the Fundamental Vulnerability of Ovarian Cancer. Cancer Discov. 2015, 5, 1137-1154. [CrossRef] [PubMed]

27. Iglehart, J.D.; Silver, D.P. Synthetic Lethality-A New Direction in Cancer-Drug Development. N. Engl. J. Med. 2009, 361, 189-191. [CrossRef]

28. Yap, T.A.; Sandhu, S.; Carden, C.P.; De Bono, J.S. Poly(ADP-Ribose) polymerase (PARP) inhibitors: Exploiting a synthetic lethal strategy in the clinic. CA Cancer J. Clin. 2011, 61, 31-49. [CrossRef]

29. Banerjee, S.; Kaye, S.B.; Ashworth, A. Making the best of PARP inhibitors in ovarian cancer. Nat. Rev. Clin. Oncol. 2010, 7, 508-519. [CrossRef]

30. Murai, J.; Huang, S.-Y.N.; DAS, B.B.; Renaud, A.; Zhang, Y.; Doroshow, J.H.; Ji, J.; Takeda, S.; Pommier, Y. Trapping of PARP1 and PARP2 by Clinical PARP Inhibitors. Cancer Res. 2012, 72, 5588-5599. [CrossRef]

31. Patel, A.; Sarkaria, J.N.; Kaufmann, S.H. Nonhomologous end joining drives poly(ADP-ribose) polymerase (PARP) inhibitor lethality in homologous recombination-deficient cells. Proc. Natl. Acad. Sci. USA 2011, 108, 3406-3411. [CrossRef]

32. Ledermann, J.; Harter, P.; Gourley, C.; Friedlander, M.; Vergote, I.; Rustin, G.; Scott, C.; Meier, W.; Shapira-Frommer, R.; Safra, T.; et al. Olaparib Maintenance Therapy in Platinum-Sensitive Relapsed Ovarian Cancer. N. Engl. J. Med. 2012, 366, $1382-1392$. [CrossRef] [PubMed]

33. Domchek, S.M.; Aghajanian, C.; Shapira-Frommer, R.; Schmutzler, R.K.; Audeh, M.W.; Friedlander, M.; Balmaña, J.; Mitchell, G.; Fried, G.; Stemmer, S.M.; et al. Efficacy and safety of olaparib monotherapy in germline BRCA1/2 mutation carriers with advanced ovarian cancer and three or more lines of prior therapy. Gynecol. Oncol. 2016, 140, 199-203. [CrossRef] [PubMed]

34. Kim, G.; Ison, G.; McKee, A.E.; Zhang, H.; Tang, S.; Gwise, T.; Sridhara, R.; Lee, E.; Tzou, A.; Philip, R.; et al. FDA Approval Summary: Olaparib Monotherapy in Patients with Deleterious Germline BRCA-Mutated Advanced Ovarian Cancer Treated with Three or More Lines of Chemotherapy. Clin. Cancer Res. 2015, 21, 4257-4261. [CrossRef]

35. Moore, K.; Colombo, N.; Scambia, G.; Kim, B.-G.; Oaknin, A.; Friedlander, M.; Lisyanskaya, A.; Floquet, A.; Leary, A.; Sonke, G.; et al. Maintenance Olaparib in Patients with Newly Diagnosed Advanced Ovarian Cancer. N. Engl. J. Med. 2018, 379, 2495-2505. [CrossRef] [PubMed]

36. Ray-Coquard, I.; Pautier, P.; Pignata, S.; Pérol, D.; Martín, A.G.; Berger, R.; Fujiwara, K.; Vergote, I.; Colombo, N.; Mäenpää, J.; et al. Olaparib plus Bevacizumab as First-Line Maintenance in Ovarian Cancer. N. Engl. J. Med. 2019, 381, 2416-2428. [CrossRef]

37. Swisher, E.M.; Lin, K.K.; Oza, A.; Scott, C.L.; Giordano, H.; Sun, J.; E Konecny, G.; Coleman, R.L.; Tinker, A.V.; O’Malley, D.M.; et al. Rucaparib in relapsed, platinum-sensitive high-grade ovarian carcinoma (ARIEL2 Part 1): An international, multicentre, openlabel, phase 2 trial. Lancet Oncol. 2017, 18, 75-87. [CrossRef]

38. Coleman, R.L.; Oza, A.; Lorusso, D.; Aghajanian, C.; Oaknin, A.; Dean, A.; Colombo, N.; Weberpals, J.I.; Clamp, A.; Scambia, G.; et al. Rucaparib maintenance treatment for recurrent ovarian carcinoma after response to platinum therapy (ARIEL3): A randomised, double-blind, placebo-controlled, phase 3 trial. Lancet 2017, 390, 1949-1961. [CrossRef]

39. Ledermann, J.A.; Oza, A.M.; Lorusso, D.; Aghajanian, C.; Oaknin, A.; Dean, A.; Colombo, N.; Weberpals, J.I.; Clamp, A.R.; Scambia, G.; et al. Rucaparib for patients with platinum-sensitive, recurrent ovarian carcinoma (ARIEL3): Post-progression outcomes and updated safety results from a randomised, placebo-controlled, phase 3 trial. Lancet Oncol. 2020, 21, 710-722. [CrossRef]

40. Mirza, M.R.; Monk, B.J.; Herrstedt, J.; Oza, A.; Mahner, S.; Redondo, A.; Fabbro, M.; Ledermann, J.A.; Lorusso, D.; Vergote, I.; et al. Niraparib Maintenance Therapy in Platinum-Sensitive, Recurrent Ovarian Cancer. N. Engl. J. Med. 2016, 375, 2154-2164. [CrossRef]

41. Martín, A.G.; Pothuri, B.; Vergote, I.; Christensen, R.D.; Graybill, W.; Mirza, M.R.; McCormick, C.; Lorusso, D.; Hoskins, P.; Freyer, G.; et al. Niraparib in Patients with Newly Diagnosed Advanced Ovarian Cancer. N. Engl. J. Med. 2019, 381, $2391-2402$. [CrossRef] [PubMed]

42. Coleman, R.L.; Fleming, G.F.; Brady, M.F.; Swisher, E.M.; Steffensen, K.D.; Friedlander, M.; Okamoto, A.; Moore, K.N.; Ben-Baruch, N.E.; Werner, T.L.; et al. Veliparib with First-Line Chemotherapy and as Maintenance Therapy in Ovarian Cancer. N. Engl. J. Med. 2019, 381, 2403-2415. [CrossRef]

43. Murai, J.; Huang, S.-Y.N.; Renaud, A.; Zhang, Y.; Ji, J.; Takeda, S.; Morris, J.; Teicher, B.; Doroshow, J.H.; Pommier, Y. Stereospecific PARP Trapping by BMN 673 and Comparison with Olaparib and Rucaparib. Mol. Cancer Ther. $2014,13,433-443$. [CrossRef] [PubMed]

44. Hoy, S.M. Talazoparib: First Global Approval. Drugs 2018, 78, 1939-1946. [CrossRef]

45. Boussios, S.; Abson, C.; Moschetta, M.; Rassy, E.; Karathanasi, A.; Bhat, T.; Ghumman, F.; Sheriff, M.; Pavlidis, N. Poly (ADP-Ribose) Polymerase Inhibitors: Talazoparib in Ovarian Cancer and Beyond. Drugs RED 2020, 20, 55-73. [CrossRef]

46. Arora, S.; Balasubramaniam, S.; Zhang, H.; Berman, T.; Narayan, P.; Suzman, D.; Bloomquist, E.; Tang, S.; Gong, Y.; Sridhara, R.; et al. FDA Approval Summary: Olaparib Monotherapy or in Combination with Bevacizumab for the Maintenance Treatment of Patients with Advanced Ovarian Cancer. Oncologist 2021, 26, e164-e172. [CrossRef]

47. Tew, W.P.; Lacchetti, C.; Ellis, A.; Maxian, K.; Banerjee, S.; Bookman, M.; Jones, M.B.; Lee, J.-M.; Lheureux, S.; Liu, J.F.; et al. PARP Inhibitors in the Management of Ovarian Cancer: ASCO Guideline. J. Clin. Oncol. 2020, 38, 3468-3493. [CrossRef] 
48. Friedlander, M.; Matulonis, U.; Gourley, C.; Du Bois, A.; Vergote, I.; Rustin, G.; Scott, C.; Meier, W.; Shapira-Frommer, R.; Safra, T.; et al. Long-term efficacy, tolerability and overall survival in patients with platinum-sensitive, recurrent high-grade serous ovarian cancer treated with maintenance olaparib capsules following response to chemotherapy. Br. J. Cancer 2018, 119, 1075-1085. [CrossRef] [PubMed]

49. Marquard, A.M.; Eklund, A.C.; Joshi, T.; Krzystanek, M.; Favero, F.; Wang, Z.C.; Richardson, A.L.; Silver, D.P.; Szallasi, Z.; Birkbak, N.J. Pan-cancer analysis of genomic scar signatures associated with homologous recombination deficiency suggests novel indications for existing cancer drugs. Biomark. Res. 2015, 3, 9. [CrossRef] [PubMed]

50. De Jonge, M.M.; Auguste, A.; Van Wijk, L.M.; Schouten, P.C.; Meijers, M.; Ter Haar, N.T.; Smit, V.T.; Nout, R.A.; Glaire, M.A.; Church, D.; et al. Frequent Homologous Recombination Deficiency in High-grade Endometrial Carcinomas. Clin. Cancer Res. 2019, 25, 1087-1097. [CrossRef]

51. Dedes, K.J.; Wetterskog, D.; Mendes-Pereira, A.M.; Natrajan, R.; Lambros, M.B.; Geyer, F.C.; Vatcheva, R.; Savage, K.; Mackay, A.; Lord, C.J.; et al. PTEN Deficiency in Endometrioid Endometrial Adenocarcinomas Predicts Sensitivity to PARP Inhibitors. Sci. Transl. Med. 2010, 2, 53ra75. [CrossRef] [PubMed]

52. Shen, J.; Peng, Y.; Wei, L.; Zhang, W.; Yang, L.; Lan, L.; Kapoor, P.; Ju, Z.; Mo, Q.; Shih, I.-M.; et al. ARID1A Deficiency Impairs the DNA Damage Checkpoint and Sensitizes Cells to PARP Inhibitors. Cancer Discov. 2015, 5, 752-767. [CrossRef] [PubMed]

53. Li, G.-M. Mechanisms and functions of DNA mismatch repair. Cell Res. 2008, 18, 85-98. [CrossRef]

54. Schlötterer, C. Evolutionary dynamics of microsatellite DNA. Chromosoma 2000, 109, 365-371. [CrossRef]

55. Bonneville, R.; Krook, M.A.; Kautto, E.; Miya, J.; Wing, M.R.; Chen, H.-Z.; Reeser, J.W.; Yu, L.; Roychowdhury, S. Landscape of Microsatellite Instability Across 39 Cancer Types. JCO Precis. Oncol. 2017, 1, 1-15. [CrossRef] [PubMed]

56. Vieira, M.L.C.; Santini, L.; Diniz, A.L.; Munhoz, C.D.F. Microsatellite markers: What they mean and why they are so useful. Genet. Mol. Biol. 2016, 39, 312-328. [CrossRef]

57. Shia, J. Evolving approach and clinical significance of detecting DNA mismatch repair deficiency in colorectal carcinoma. Semin. Diagn. Pathol. 2015, 32, 352-361. [CrossRef]

58. Deshpande, M.; Romanski, P.A.; Rosenwaks, Z.; Gerhardt, J. Gynecological Cancers Caused by Deficient Mismatch Repair and Microsatellite Instability. Cancers 2020, 12, 3319. [CrossRef]

59. Lynch, H.T.; Snyder, C.L.; Shaw, T.G.; Heinen, C.D.; Hitchins, M.P. Milestones of Lynch syndrome: 1895-2015. Nat. Rev. Cancer 2015, 15, 181-194. [CrossRef] [PubMed]

60. Watson, P.; Lynch, H.T. The tumor spectrum in HNPCC. Anticancer Res. 1994, 14, 1635-1639.

61. Møller, P.; Seppälä, T.; Bernstein, I.; Holinski-Feder, E.; Sala, P.; Evans, G.; Lindblom, A.; Macrae, F.; Blanco, I.; Sijmons, R.; et al. Cancer incidence and survival in Lynch syndrome patients receiving colonoscopic and gynaecological surveillance: First report from the prospective Lynch syndrome database. Gut 2017, 66, 464-472. [CrossRef]

62. Kane, M.F.; Loda, M.; Gaida, G.M.; Lipman, J.; Mishra, R.; Goldman, H.; Jessup, J.M.; Kolodner, R. Methylation of the hMLH1 promoter correlates with lack of expression of hMLH1 in sporadic colon tumors and mismatch repair-defective human tumor cell lines. Cancer Res. 1997, 57, 808-811.

63. Kakar, S.; Burgart, L.J.; Thibodeau, S.N.; Rabe, K.G.; Petersen, G.M.; Goldberg, R.M.; Lindor, N.M. Frequency of loss of hMLH1 expression in colorectal carcinoma increases with advancing age. Cancer 2003, 97, 1421-1427. [CrossRef] [PubMed]

64. Simpkins, S.B.; Bocker, T.; Swisher, E.M.; Mutch, D.G.; Gersell, D.J.; Kovatich, A.J.; Palazzo, J.P.; Fishel, R.; Goodfellow, P.J. MLH1 Promoter Methylation and Gene Silencing is the Primary Cause of Microsatellite Instability in Sporadic Endometrial Cancers. Hum. Mol. Genet. 1999, 8, 661-666. [CrossRef]

65. Jensen, K.C.; Mariappan, M.R.; Putcha, G.V.; Husain, A.; Chun, N.; Ford, J.M.; Schrijver, I.; Longacre, T.A. Microsatellite Instability and Mismatch Repair Protein Defects in Ovarian Epithelial Neoplasms in Patients 50 Years of Age and Younger. Am. J. Surg. Pathol. 2008, 32, 1029-1037. [CrossRef]

66. Murphy, M.A.; Wentzensen, N. Frequency of mismatch repair deficiency in ovarian cancer: A systematic review This article is a US Government work and, as such, is in the public domain of the United States of America. Int. J. Cancer 2010, 129, 1914-1922. [CrossRef] [PubMed]

67. Pal, T.; Permuth-Wey, J.; Kumar, A.; Sellers, T.A. Systematic Review and Meta-analysis of Ovarian Cancers: Estimation of Microsatellite-High Frequency and Characterization of Mismatch Repair Deficient Tumor Histology. Clin. Cancer Res. 2008, 14, 6847-6854. [CrossRef] [PubMed]

68. Helder-Woolderink, J.; Blok, E.; Vasen, H.; Hollema, H.; Mourits, M.; De Bock, G. Ovarian cancer in Lynch syndrome; a systematic review. Eur. J. Cancer 2016, 55, 65-73. [CrossRef] [PubMed]

69. Hacking, S.; Jin, C.; Komforti, M.; Liang, S.; Nasim, M. MMR deficient undifferentiated/dedifferentiated endometrial carcinomas showing significant programmed death ligand-1 expression (sp 142) with potential therapeutic implications. Pathol. Res. Pract. 2019, 215, 152552. [CrossRef]

70. Hempelmann, J.A.; Lockwood, C.; Konnick, E.; Schweizer, M.T.; Antonarakis, E.S.; Lotan, T.L.; Montgomery, B.; Nelson, P.S.; Klemfuss, N.; Salipante, S.J.; et al. Microsatellite instability in prostate cancer by PCR or next-generation sequencing. J. Immunother. Cancer 2018, 6, 29. [CrossRef] [PubMed]

71. Cheah, P.L.; Li, J.; Looi, L.M.; Koh, C.C.; Lau, T.P.; Chang, S.W.; Teoh, K.H.; Mun, K.S.; Nazarina, A.R. Screening for microsatellite instability in colorectal carcinoma: Practical utility of immunohistochemistry and PCR with fragment analysis in a diagnostic histopathology setting. Malays J. Pathol. 2019, 41, 91-100. [PubMed] 
72. Waalkes, A.; Smith, N.; Penewit, K.; Hempelmann, J.; Konnick, E.; Hause, R.; Pritchard, C.C.; Salipante, S.J. Accurate PanCancer Microsatellite instability in prostate cancer by PCR or next-generation sequencing Probe Capture and High-Throughput Sequencing. Clin. Chem. 2018, 64, 950-958. [CrossRef]

73. Arulananda, S.; Thapa, B.; Walkiewicz, M.; Zapparoli, G.V.; Williams, D.S.; Dobrovic, A.; John, T. Mismatch Repair Protein Defects and Microsatellite Instability in Malignant Pleural Mesothelioma. J. Thorac. Oncol. 2018, 13, 1588-1594. [CrossRef] [PubMed]

74. Dedeurwaerdere, F.; Claes, K.B.; Van Dorpe, J.; Rottiers, I.; Van der Meulen, J.; Breyne, J.; Swaerts, K.; Martens, G. Comparison of microsatellite instability detection by immunohistochemistry and molecular techniques in colorectal and endometrial cancer. Sci. Rep. 2021, 11, 12880. [CrossRef]

75. Boland, C.R.; Thibodeau, S.N.; Hamilton, S.R.; Sidransky, D.; Eshleman, J.R.; Burt, R.W.; Meltzer, S.J.; Rodriguez-Bigas, M.A.; Fodde, R.; Ranzani, G.; et al. A National Cancer Institute Workshop on Microsatellite Instability for cancer detection and familial predisposition: Development of international criteria for the determination of microsatellite instability in colorectal cancer. Cancer Res. 1998, 58, 5248-5257. [PubMed]

76. Baudrin, L.G.; Deleuze, J.-F.; How-Kit, A. Molecular and Computational Methods for the Detection of Microsatellite Instability in Cancer. Front. Oncol. 2018, 8, 621. [CrossRef]

77. Vilar, E.; Gruber, S.B. Microsatellite instability in colorectal cancer-The stable evidence. Nat. Rev. Clin. Oncol. 2010, 7, 153-162. [CrossRef] [PubMed]

78. Cancer Genome Atlas Network. Comprehensive molecular characterization of human colon and rectal cancer. Nature 2012, 487, 330-337. [CrossRef] [PubMed]

79. Howitt, B.E.; Shukla, S.A.; Sholl, L.M.; Ritterhouse, L.L.; Watkins, J.C.; Rodig, S.; Stover, E.; Strickland, K.; D'Andrea, A.D.; Wu, C.J.; et al. Association of Polymerase e-Mutated and Microsatellite-Instable Endometrial Cancers with Neoantigen Load, Number of Tumor-Infiltrating Lymphocytes, and Expression of PD-1 and PD-L1. JAMA Oncol. 2015, 1, 1319-1323. [CrossRef]

80. Howitt, B.E.; Strickland, K.C.; Sholl, L.M.; Rodig, S.; Ritterhouse, L.L.; Chowdhury, D.; D'Andrea, A.D.; Matulonis, U.A.; Konstantinopoulos, P.A. Clear cell ovarian cancers with microsatellite instability: A unique subset of ovarian cancers with increased tumor-infiltrating lymphocytes and PD-1/PD-L1 expression. OncoImmunology 2017, 6, e1277308. [CrossRef] [PubMed]

81. Lemery, S.; Keegan, P.; Pazdur, R. First FDA Approval Agnostic of Cancer Site-When a Biomarker Defines the Indication. N. Engl. J. Med. 2017, 377, 1409-1412. [CrossRef]

82. Le, D.T.; Uram, J.N.; Wang, H.; Bartlett, B.; Kemberling, H.; Eyring, A.D.; Skora, A.D.; Luber, B.S.; Azad, N.S.; Laheru, D.; et al. PD-1 Blockade in Tumors with Mismatch-Repair Deficiency. N. Engl. J. Med. 2015, 372, 2509-2520. [CrossRef] [PubMed]

83. Marabelle, A.; Le, D.T.; Ascierto, P.A.; Di Giacomo, A.M.; De Jesus-Acosta, A.; Delord, J.-P.; Geva, R.; Gottfried, M.; Penel, N.; Hansen, A.; et al. Efficacy of Pembrolizumab in Patients with Noncolorectal High Microsatellite Instability/Mismatch Repair-Deficient Cancer: Results from the Phase II KEYNOTE-158 Study. J. Clin. Oncol. 2020, 38, 1-10. [CrossRef]

84. Makker, V.; Taylor, M.H.; Aghajanian, C.; Oaknin, A.; Mier, J.; Cohn, A.L.; Romeo, M.; Bratos, R.; Brose, M.S.; DiSimone, C.; et al. Lenvatinib Plus Pembrolizumab in Patients with Advanced Endometrial Cancer. J. Clin. Oncol. 2020, 38, 2981-2992. [CrossRef]

85. Mantovani, F.; Collavin, L.; Del Sal, G. Mutant p53 as a guardian of the cancer cell. Cell Death Differ. 2019, 26, 199-212. [CrossRef]

86. Zhu, G.; Pan, C.; Bei, J.-X.; Li, B.; Liang, C.; Xu, Y.; Fu, X. Mutant p53 in Cancer Progression and Targeted Therapies. Front. Oncol. 2020, 10, 595187. [CrossRef] [PubMed]

87. Mohell, N.; Alfredsson, J.; Fransson, A.; Uustalu, M.; Bystrom, S.; Gullbo, J.; Hallberg, A.; Bykov, V.J.N.; Bjorklund, U.; Wiman, K. APR-246 overcomes resistance to cisplatin and doxorubicin in ovarian cancer cells. Cell Death Dis. 2015, 6, e1794. [CrossRef]

88. Bridges, K.A.; Hirai, H.; Buser, C.A.; Brooks, C.; Liu, H.; Buchholz, T.; Molkentine, J.; Mason, K.A.; Meyn, R.E. MK-1775, a Novel Wee1 Kinase Inhibitor, Radiosensitizes p53-Defective Human Tumor Cells. Clin. Cancer Res. 2011, 17, 5638-5648. [CrossRef] [PubMed]

89. Hirai, H.; Iwasawa, Y.; Okada, M.; Arai, T.; Nishibata, T.; Kobayashi, M.; Kimura, T.; Kaneko, N.; Ohtani, J.; Yamanaka, K.; et al. Small-molecule inhibition of Wee1 kinase by MK-1775 selectively sensitizes p53-deficient tumor cells to DNA-damaging agents. Mol. Cancer Ther. 2009, 8, 2992-3000. [CrossRef]

90. Oza, A.M.; Estevez-Diz, M.D.P.; Grischke, E.-M.; Hall, M.; Marmé, F.; Provencher, D.M.; Uyar, D.S.; Weberpals, J.I.; Wenham, R.M.; Laing, N.; et al. A Biomarker-enriched, Randomized Phase II Trial of Adavosertib (AZD1775) Plus Paclitaxel and Carboplatin for Women with Platinum-sensitive TP53-mutant Ovarian Cancer. Clin. Cancer Res. 2020, 26, 4767-4776. [CrossRef]

91. Lheureux, S.; Cristea, M.C.; Bruce, J.P.; Garg, S.; Cabanero, M.; Mantia-Smaldone, G.; Olawaiye, A.B.; Ellard, S.L.; Weberpals, J.I.; Hendrickson, A.E.W.; et al. Adavosertib plus gemcitabine for platinum-resistant or platinum-refractory recurrent ovarian cancer: A double-blind, randomised, placebo-controlled, phase 2 trial. Lancet 2021, 397, 281-292. [CrossRef]

92. Liu, J.F.; Xiong, N.; Campos, S.M.; Wright, A.A.; Krasner, C.; Schumer, S.; Horowitz, N.; Veneris, J.; Tayob, N.; Morrissey, S.; et al. Phase II Study of the WEE1 Inhibitor Adavosertib in Recurrent Uterine Serous Carcinoma. J. Clin. Oncol. 2021, 39, 1531-1539. [CrossRef] [PubMed]

93. Deniger, D.C.; Pasetto, A.; Robbins, P.F.; Gartner, J.J.; Prickett, T.D.; Paria, B.C.; Malekzadeh, P.; Jia, L.; Yossef, R.; Langhan, M.M.; et al. T-cell Responses to TP53 “Hotspot" Mutations and Unique Neoantigens Expressed by Human Ovarian Cancers. Clin. Cancer Res. 2018, 24, 5562-5573. [CrossRef] [PubMed]

94. Malekzadeh, P.; Yossef, R.; Cafri, G.; Paria, B.C.; Lowery, F.J.; Jafferji, M.; Good, M.L.; Sachs, A.; Copeland, A.R.; Kim, S.P.; et al. Antigen Experienced T Cells from Peripheral Blood Recognize p53 Neoantigens. Clin. Cancer Res. 2020, 26, 1267-1276. [CrossRef]

95. Hausen, H.Z. Papillomaviruses and cancer: From basic studies to clinical application. Nat. Rev. Cancer 2002, 2, 342-350. [CrossRef] 
96. Pal, A.; Kundu, R. Human Papillomavirus E6 and E7: The Cervical Cancer Hallmarks and Targets for Therapy. Front. Microbiol. 2020, 10, 3116. [CrossRef] [PubMed]

97. Szymonowicz, K.; Chen, J. Biological and clinical aspects of HPV-related cancers. Cancer Biol. Med. 2020, 17, 864-878. [CrossRef]

98. Duensing, S.; Lee, L.Y.; Duensing, A.; Basile, J.; Piboonniyom, S.-O.; Gonzalez, S.; Crum, C.P.; Münger, K. The human papillomavirus type $16 \mathrm{E} 6$ and E7 oncoproteins cooperate to induce mitotic defects and genomic instability by uncoupling centrosome duplication from the cell division cycle. Proc. Natl. Acad. Sci. USA 2000, 97, 10002-10007. [CrossRef]

99. Warren, C.; Xu, T.; Guo, K.; Griffin, L.M.; Westrich, J.; Lee, D.; Lambert, P.F.; Santiago, M.L.; Pyeon, D. APOBEC3A Functions as a Restriction Factor of Human Papillomavirus. J. Virol. 2014, 89, 688-702. [CrossRef] [PubMed]

100. Ojesina, A.I.; Lichtenstein, L.; Freeman, S.S.; Pedamallu, C.S.; Imaz-Rosshandler, I.; Pugh, T.J.; Cherniack, A.D.; Ambrogio, L.; Cibulskis, K.; Bertelsen, B.; et al. Landscape of genomic alterations in cervical carcinomas. Nature 2014, 506, 371-375. [CrossRef]

101. Rusan, M.; Li, Y.Y.; Hammerman, P.S. Genomic Landscape of Human Papillomavirus-Associated Cancers. Clin. Cancer Res. 2015, 21, 2009-2019. [CrossRef] [PubMed]

102. Cheung, L.W.; Hennessy, B.T.; Li, J.; Yu, S.; Myers, A.P.; Djordjevic, B.; Lu, Y.; Stemke-Hale, K.; Dyer, M.D.; Zhang, F.; et al. High Frequency of PIK3R1 and PIK3R2 Mutations in Endometrial Cancer Elucidates a Novel Mechanism for Regulation of PTEN Protein Stability. Cancer Discov. 2011, 1, 170-185. [CrossRef] [PubMed]

103. Nero, C.; Ciccarone, F.; Pietragalla, A.; Scambia, G. PTEN and Gynecological Cancers. Cancers 2019, 11, 1458. [CrossRef] [PubMed]

104. Dedes, K.J.; Wetterskog, D.; Ashworth, A.; Kaye, S.B.; Reis-Filho, J.S. Emerging therapeutic targets in endometrial cancer. Nat. Rev. Clin. Oncol. 2011, 8, 261-271. [CrossRef]

105. Liu, P.; Cheng, H.; Roberts, T.M.; Zhao, J.J. Targeting the phosphoinositide 3-kinase pathway in cancer. Nat. Rev. Drug Discov. 2009, 8, 627-644. [CrossRef] [PubMed]

106. Shen, W.; Balajee, A.S.; Wang, J.; Wu, H.; Eng, C.; Pandolfi, P.P.; Yin, Y. Essential Role for Nuclear PTEN in Maintaining Chromosomal Integrity. Cell 2007, 128, 157-170. [CrossRef]

107. Philip, C.-A.; Laskov, I.; Beauchamp, M.-C.; Marques, M.; Amin, O.; Bitharas, J.; Kessous, R.; Kogan, L.; Baloch, T.; Gotlieb, W.H.; et al. Inhibition of PI3K-AKT-mTOR pathway sensitizes endometrial cancer cell lines to PARP inhibitors. BMC Cancer 2017, 17, 638. [CrossRef]

108. Bian, X.; Gao, J.; Luo, F.; Rui, C.; Zheng, T.; Wang, D.; Wang, Y.; Roberts, T.M.; Liu, P.; Zhao, J.J.; et al. PTEN deficiency sensitizes endometrioid endometrial cancer to compound PARP-PI3K inhibition but not PARP inhibition as monotherapy. Oncogene 2018, 37, 341-351. [CrossRef]

109. Shorstova, T.; Foulkes, W.D.; Witcher, M. Achieving clinical success with BET inhibitors as anti-cancer agents. Br. J. Cancer 2021, 124, 1478-1490. [CrossRef]

110. Van der Ploeg, P.; Uittenboogaard, A.; Thijs, A.M.; Westgeest, H.M.; Boere, I.A.; Lambrechts, S.; van de Stolpe, A.; Bekkers, R.L.; Piek, J.M. The effectiveness of monotherapy with PI3K/AKT/mTOR pathway inhibitors in ovarian cancer: A meta-analysis. Gynecol. Oncol. 2021. In Press. [CrossRef] [PubMed]

111. Gallyas, F., Jr.; Sumegi, B.; Szabo, C. Role of Akt Activation in PARP Inhibitor Resistance in Cancer. Cancers 2020, 12, 532. [CrossRef]

112. Fares, C.; Van Allen, E.M.; Drake, C.G.; Allison, J.P.; Hu-Lieskovan, S. Mechanisms of Resistance to Immune Checkpoint Blockade: Why Does Checkpoint Inhibitor Immunotherapy Not Work for All Patients? Am. Soc. Clin. Oncol. Educ. Book 2019, 39, 147-164. [CrossRef] [PubMed]

113. Hodges, H.C.; Kirkland, J.; Crabtree, G.R. The Many Roles of BAF (mSWI/SNF) and PBAF Complexes in Cancer. Cold Spring Harb. Perspect. Med. 2016, 6, a026930. [CrossRef]

114. Liu, G.; Xu, P.; Fu, Z.; Hua, X.; Liu, X.; Li, W.; Zhang, M.; Wu, J.; Wen, J.; Xu, J.; et al. Prognostic and Clinicopathological Significance of ARID1A in Endometrium-Related Gynecological Cancers: A Meta-Analysis. J. Cell. Biochem. 2017, 118, 4517-4525. [CrossRef] [PubMed]

115. Toumpeki, C.; Liberis, A.; Tsirkas, I.; Tsirka, T.; Kalagasidou, S.; Inagamova, L.; Anthoulaki, X.; Tsatsaris, G.; Kontomanolis, E.N. The Role of ARID1A in Endometrial Cancer and the Molecular Pathways Associated with Pathogenesis and Cancer Progression. In Vivo 2019, 33, 659-667. [CrossRef]

116. Kawahara, N.; Yamada, Y.; Kobayashi, H. CCNE1 Is a Putative Therapeutic Target for ARID1A-Mutated Ovarian Clear Cell Carcinoma. Int. J. Mol. Sci. 2021, 22, 5869. [CrossRef] [PubMed]

117. Ge, H.; Xiao, Y.; Qin, G.; Gu, Y.; Cai, X.; Jiang, W.; Tu, X.; Yang, W.; Bi, R. Mismatch repair deficiency is associated with specific morphologic features and frequent loss of ARID1A expression in ovarian clear cell carcinoma. Diagn. Pathol. 2021, 16, 12. [CrossRef]

118. Berns, K.; Caumanns, J.J.; Hijmans, E.M.; Gennissen, A.M.C.; Severson, T.M.; Evers, B.; Wisman, G.B.A.; Meersma, G.J.; Lieftink, C.; Beijersbergen, R.; et al. ARID1A mutation sensitizes most ovarian clear cell carcinomas to BET inhibitors. Oncogene 2018, 37, 4611-4625. [CrossRef]

119. Mita, M.M.; Mita, A.C. Bromodomain inhibitors a decade later: A promise unfulfilled? Br. J. Cancer 2020, 123, 1713-1714. [CrossRef] [PubMed]

120. Shen, J.; Ju, Z.; Zhao, W.; Wang, L.; Peng, Y.; Ge, Z.; Nagel, Z.D.; Zou, J.; Wang, C.; Kapoor, P.; et al. ARID1A deficiency promotes mutability and potentiates therapeutic antitumor immunity unleashed by immune checkpoint blockade. Nat. Med. 2018, 24, 556-562. [CrossRef] 
121. Chandler, R.L.; Damrauer, J.S.; Raab, J.; Schisler, J.; Wilkerson, M.D.; Didion, J.; Starmer, J.; Serber, D.W.; Yee, D.; Xiong, J.; et al. Coexistent ARID1A-PIK3CA mutations promote ovarian clear-cell tumorigenesis through pro-tumorigenic inflammatory cytokine signalling. Nat. Commun. 2015, 6, 6118. [CrossRef] [PubMed]

122. Sun, C.; Yin, J.; Fang, Y.; Chen, J.; Jeong, K.J.; Chen, X.; Vellano, C.P.; Ju, Z.; Zhao, W.; Zhang, D.; et al. BRD4 Inhibition Is Synthetic Lethal with PARP Inhibitors through the Induction of Homologous Recombination Deficiency. Cancer Cell 2018, 33, 401-416.e8. [CrossRef] [PubMed]

123. Da Costa, A.A.B.A.; Canto, L.M.D.; Larsen, S.J.; Ribeiro, A.R.G.; Stecca, C.E.; Petersen, A.H.; Aagaard, M.M.; De Brot, L.; Baumbach, J.; Baiocchi, G.; et al. Genomic profiling in ovarian cancer retreated with platinum based chemotherapy presented homologous recombination deficiency and copy number imbalances of CCNE1 and RB1 genes. BMC Cancer 2019, 19, 422. [CrossRef]

124. Ledermann, J.A.; Drew, Y.; Kristeleit, R.S. Homologous recombination deficiency and ovarian cancer. Eur. J. Cancer 2016, 60, 49-58. [CrossRef] [PubMed]

125. Leijen, S.; Van Geel, R.M.J.M.; Sonke, G.; De Jong, D.; Rosenberg, E.; Marchetti, S.; Pluim, D.; van Werkhoven, E.; Rose, S.; Lee, M.A.; et al. Phase II Study of WEE1 Inhibitor AZD1775 Plus Carboplatin in Patients With TP53-Mutated Ovarian Cancer Refractory or Resistant to First-Line Therapy Within 3 Months. J. Clin. Oncol. 2016, 34, 4354-4361. [CrossRef] [PubMed]

126. Joshi, P.; Sutor, S.L.; Huntoon, C.J.; Karnitz, L.M. Ovarian Cancer-associated Mutations Disable Catalytic Activity of CDK12, a Kinase That Promotes Homologous Recombination Repair and Resistance to Cisplatin and Poly(ADP-ribose) Polymerase Inhibitors. J. Biol. Chem. 2014, 289, 9247-9253. [CrossRef]

127. Fader, A.N.; Roque, D.M.; Siegel, E.; Buza, N.; Hui, P.; Abdelghany, O.; Chambers, S.K.; Secord, A.A.; Havrilesky, L.; O’Malley, D.M.; et al. Randomized Phase II Trial of Carboplatin-Paclitaxel Versus Carboplatin-Paclitaxel-Trastuzumab in Uterine Serous Carcinomas That Overexpress Human Epidermal Growth Factor Receptor 2/neu. J. Clin. Oncol. 2018, 36, 2044-2051. [CrossRef]

128. Takeda, T.; Banno, K.; Okawa, R.; Yanokura, M.; Iijima, M.; Irie-Kunitomi, H.; Nakamura, K.; Iida, M.; Adachi, M.; Umene, K.; et al ARID1A gene mutation in ovarian and endometrial cancers (Review). Oncol. Rep. 2015, 35, 607-613. [CrossRef] [PubMed]

129. Jones, B.; Varambally, S.; Arend, R.C. Histone Methyltransferase EZH2: A Therapeutic Target for Ovarian Cancer. Mol. Cancer Ther. 2018, 17, 591-602. [CrossRef]

130. De Luca, A.; Maiello, M.R.; Alessio, A.D.; Pergameno, M.; Normanno, N. The RAS/RAF/MEK/ERK and the PI3K/AKT signalling pathways: Role in cancer pathogenesis and implications for therapeutic approaches. Expert Opin. Ther. Targets 2012, 16 (Suppl. 2), S17-S27. [CrossRef] 